\title{
Heaping of Executive Compensation
}

\author{
Bjorn N. Jorgensen \\ London School of Economics and Political Science \\ b.n.jorgensen@1se.ac.uk \\ Paige H. Patrick \\ University of Washington \\ patrickp@uw.edu \\ Naomi S. Soderstrom \\ University of Melbourne \\ naomiss@unimelb.edu.au
}

Running Head: Heaping of Executive Compensation

We thank two anonymous referees, Shane Dikolli (editor), Brian Cadman, Frank Moers, Steve Rock, Hongtao Shen (discussant, 2014 JMAR/CJAS conference in Wuhan, China), and seminar participants at University of Aachen, UBCOW, University of Colorado at Boulder, University of Edinburgh, University of Hohenheim, IE Business School, INSEAD, LaTrobe University, LSE, University of Maastricht, Macquarie University, Monash University, Peking University, and University of Queensland for helpful comments. 


\title{
Heaping of Executive Compensation
}

\begin{abstract}
We investigate whether compensation grants are subject to "heaping", the tendency of less informed individuals to provide round values when reporting estimates of discrete data. We document that an unexpectedly large number of CEOs receive round compensation (i.e., evenly divisible by 100,000 and/or 10,000). We investigate whether consistent with heaping, frequency of round compensation varies with proxies for boards of directors' effort in setting compensation. We find that round compensation is more common when boards have characteristics suggesting they provide weak oversight of compensation and thus face more uncertainty in estimating compensation. We also find less frequent round compensation when boards face stronger pressure from external stakeholders, encouraging boards to expend additional cognitive effort in setting compensation. Further, consistent with weak oversight of compensation, round compensation tends to be higher than non-round compensation. However, we do not find a consistent association between this higher, round compensation and future firm performance.
\end{abstract}

Keywords: Executive compensation, heaping, rounding, Say on Pay.

JEL Classifications: G30, G41, M40, M46

Data Availability: Data are available from the public sources cited in the text.

\section{INTRODUCTION}

Empirical research on executive compensation typically appeals to models based on agency theory to help explain how boards of directors incentivize executives. These models assume numerous functional forms for compensation. However, to our knowledge, none of these models predicts that the distribution of compensation will include discontinuities. Some models do predict that individual CEO compensation may reflect discontinuous earnings distributions (e.g., Healy 1985; Melumad 1989; Fedyk 2007); however, these models do not suggest that the distribution of CEO compensation across many heterogeneous firms and years will include discontinuities. 
While analytical models based on the agency theory framework do not predict discontinuities in the distribution of executive compensation, research that reflects behavioral phenomena does predict that discontinuities will occur. We investigate whether the heuristic response to uncertainty known as "heaping" partially explains the observed distribution of executive compensation. ${ }^{1}$ Heaping is the tendency to provide estimates ending in digits that are the largest divisors of the base number system. Heaping arises when people make point estimates of measures about which they lack precise information (Turner 1958). That is, when individuals have imprecise information, they provide estimates that follow a predictable pattern: the estimates tend to be multiples of the base of the number system, i.e., round numbers. The existence of heaping is widely acknowledged in disciplines such as demography, where researchers frequently rely on self-reported information by imperfectly informed individuals. Studies in diverse fields find evidence of heaping when individuals are uncertain about the actual values of measures, such as income (Turner 1958), birthweight (Barecca, Guldi, Lindo, and Waddell 2011), blood pressure, and age (Roberts and Brewer 2001). For example, individuals are less likely to provide round estimates when they provide their own ages but are more likely to provide round estimates when they provide estimates of others' ages. In accounting, empirical researchers document discontinuities in distributions of analyst and management forecasts, both of which are reported estimates (e.g., Hermann and Thomas 2004; Bamber, Hui, and Yeung 2010; Zhou 2010; Dechow and You 2012; Athanasakou and Simpson 2016). Consistent with heaping, these studies find that both analysts and management tend to report round values of forecasted earnings when they are less certain of the estimates they are providing.

\footnotetext{
${ }^{1}$ While heaping is a behavior that arises in the face of uncertainty, we do not argue that heaping is necessarily economically irrational. As we discuss below, heaping may be consistent with boards expending efficient levels of effort on costly information acquisition and processing.
} 
Prior literature on executive compensation in accounting and finance largely explores whether compensation is structured in a fashion consistent with agency theory models that represent competitive market forces, or with managerial power over compensation (see Frydman and Jenter 2010 for a review). We build upon the existing understanding of how boards set compensation by investigating the role of heaping in determining compensation. We explore whether the distribution of compensation is consistent with heaping behavior. If executive compensation reflects heaping, the distribution of executive compensation will exhibit abnormally high levels of round compensation (i.e., compensation that is a multiple of the base ten numerical system) and these round values of compensation will vary predictably with proxies for the level of directors' uncertainty about executive performance and optimal compensation design.

To address whether distributions of compensation exhibit abnormally high levels of round compensation, we present evidence of the frequency of round CEO compensation values. We document that an unusually high number of executives earn round compensation. ${ }^{2}$ Figure 1 illustrates this phenomenon for different components of CEO compensation. In our sample, 36.1 percent of CEO salaries, 40.9 percent of bonuses, and 23.8 percent of option grants are evenly divisible by either 100,000 or $10,000{ }^{3}$ This phenomenon does not appear to be based upon a mechanical relation between compensation and the underlying performance metrics upon which it is based, since two commonly used performance measures, earnings per share and stock price, end in zero only 9.3 percent and 11.3 percent of the time, respectively. Thus, we provide

\footnotetext{
${ }^{2}$ We limit our measure of rounding to compensation components that are rounded to 100,000 s or 10,000 s of dollars or shares granted to capture meaningful levels of rounding.

${ }^{3}$ We exclude observations of $\$ 0$ or 0 shares from our analyses. Thus, these values represent the frequencies with which non-zero compensation is rounded.
} 
evidence that executive compensation exhibits abnormally high frequencies of round compensation.

We perform three sets of analyses to assess whether round values of compensation vary predictably with proxies for the level of directors' uncertainty about executive performance and the design of optimal compensation, which would suggest that the distribution of CEO compensation is consistent with heaping. First, we consider whether round compensation is more common when boards have characteristics that indicate weak oversight of compensation. In these firms, we expect that directors will be less likely to have acquired and processed the information necessary to make precise estimates about executive performance. This may arise for a number of reasons: (i) weak boards are unlikely to challenge powerful executives who take measures to obfuscate relevant information about performance; (ii) directors on such boards are less likely to be responsive to pressure from outside parties; or (iii) such directors are not motivated by reputation concerns. Thus, if round compensation results from heaping, it will be positively associated with proxies for weak board oversight. A substantial stream of literature demonstrates that certain board characteristics are consistent with weaker oversight of compensation (e.g., Core, Holthausen, and Larcker 1999; Coles, Daniel, and Naveen 2014). Our evidence is consistent with this prediction. We show that round compensation is more common when the board has a greater proportion of insiders and a greater proportion of directors appointed by the CEO.

Second, we investigate whether stakeholder pressure is associated with round compensation. Prior research suggests that boards increase attention and effort in setting compensation in the presence of more active stakeholders (e.g., Johnson, Porter, and Shackell 1997; Thomas and Martin, 1999; Core, Guay, and Larcker 2008; Ertimur, Ferri, and Muslu 2011; 
Abernethy, Kuang, and Qin 2015; Ertimur, Ferri, and Oesch 2018). If boards increase the cognitive effort they expend on setting compensation when they face greater stakeholder pressure, they will be more informed, reducing uncertainty about executive performance and about how to set optimal compensation. As such, if round compensation is consistent with heaping, greater stakeholder pressure will be associated with a lower incidence of round compensation. We examine the change in the frequency of round compensation following passage of the Say on Pay provision of the Dodd-Frank Act, ${ }^{4}$ which requires an advisory shareholder vote on executive compensation packages. This passage of compensation-related regulation is a reasonable proxy for changes in stakeholder pressure because it is at least partially exogenous to individual firms' governance environments. Additionally, this identification strategy exploits within-firm variation in stakeholder scrutiny surrounding regulatory changes, allowing us to make stronger inferences about the effect of stakeholder scrutiny on the frequency of rounding. We find evidence consistent with our expectations. Boards are less likely to grant round values of compensation components after passage of Say on Pay, particularly for performance-based pay, which was the focus of that regulation. In sensitivity tests, we find a similar reduction in rounding of option grants following passage of Statement of Financial Accounting Standards No. 123R (SFAS 123R) - Share-Based Payment. ${ }^{5}$

Third, we investigate whether, controlling for firm performance, round CEO compensation tends to be higher than non-round CEO compensation. Bebchuk and Fried (2003) suggest that self-interested managers take advantage of opportunities to extract rents from firms

\footnotetext{
${ }^{4}$ Dodd-Frank Wall Street Reform and Consumer Protection Act (2010).

${ }^{5}$ Statement of Financial Accounting Standards No. 123: Accounting for Stock-Based Compensation allowed firms to account for option compensation using the intrinsic value method on the option grant date (usually zero) and required disclosure of the grant date fair value of option compensation expense. SFAS 123R required firms to recognize option expense at grant date fair value rather than intrinsic value.
} 
in the form of excess compensation. Round compensation as a result of heaping suggests that boards granting round compensation face more uncertainty when setting compensation than do boards granting nonround compensation. Self-interested CEOs may take advantage of this uncertainty to gain excess compensation. This suggests that round compensation will be greater than non-round compensation for a given level of performance. We find evidence consistent with this prediction. After controlling for firm-level determinants of compensation, we show that total compensation is higher when it is round.

These analyses provide consistent evidence that heaping frequently occurs when boards set executive compensation. Our final analysis investigates whether heaping is detrimental to firm performance. On the one hand, heaping may be associated with poorer future firm performance if heaping occurs when boards do not provide strong oversight of compensation, allowing self-interested managers to extract material rents via compensation. On the other, hand, heaping of compensation may result from an efficient allocation of board attention. Boards have many tasks in addition to setting CEO compensation, but a limited amount of attention to allocate across these competing tasks. If these competing tasks are economically important, a lack of attention to the details of compensation can be desirable. We find mixed evidence of an association between round compensation and future firm performance. As such, we are unable to conclude whether, on average, heaping of executive compensation is detrimental to firm performance, or represents efficient allocation of limited board attention across multiple tasks.

In sum, we provide evidence that, in addition to being driven by agency cost concerns and managerial power as shown in prior literature, executive compensation also reflects behavioral tendencies. Specifically, we demonstrate that executive compensation exhibits characteristics consistent with heaping, which is the tendency of uninformed individuals to 
provide round numbers when they estimate discrete, quantitative data. We show that round compensation is common and that the attributes of this round compensation are consistent with less-informed boards. These findings contribute to our understanding of how boards determine compensation. We also contribute to the literature on discontinuities in executive compensation distributions. Prior research documents that an unusually high number of executives earn salaries of \$1 million (Rose and Wolfram 2000, 2002) or of \$0/\$1 (Hamm, Jung and Wang 2015; Loureiro, Makhija, and Zhang 2015). In addition to these focal points, we document an unusually high number of executives earning round compensation, that is, compensation components that are rounded to 100,000 s or 10,000 s of dollars or shares granted.

We also extend the literature on heaping to a new setting - compensation. Heaping has been widely acknowledged in other disciplines, and has received some attention in the financial accounting literature, as well. Prior studies in accounting find evidence of heaping in analyst and

management forecasts (e.g., Hermann and Thomas 2004; Bamber et al. 2010; Zhou 2010; Dechow and You 2012; Athanasakou and Simpson 2016). We expand upon these prior studies by demonstrating that heaping affects additional firm stakeholders, boards of directors and firm executives.

\section{LITERATURE REVIEW}

Psychology literature explores how individuals retrieve uncertain values from memory, and explains individuals' reliance on arithmetic prototypes (i.e., round numbers) when reporting these uncertain values (e.g., Huttenlocher, Hedges and Bradburn 1990). Social sciences research also observes this behavior when individuals make estimates of uncertain information, even 
when individuals are not retrieving this information from memory. ${ }^{6}$ The social science literature coins the term "heaping" to describe the tendency to provide estimates ending in digits that are the largest divisors of the base number system. In this literature, heaping is considered a heuristic response to uncertainty that arises when people make point estimates of measures about which they lack precise information. Simon (1990) and Shah and Oppenheimer (2008) link heuristics to reduced effort associated with decision processes.

In accounting, a handful of studies investigate whether heaping is present in distributions of earnings estimates. Herrmann and Thomas (2005), Zhou (2010), and Dechow and You (2012) find that analysts' forecasts of EPS exhibit more clustering around multiples of five cents than do actual EPS. Consistent with heaping, these studies find that analysts who round EPS forecasts appear to be less informed, exert less effort, and have fewer resources. Bamber et al. (2010) investigate whether heaping is present in management's earnings forecasts. In addition to reflecting uncertainty, they find that round management forecasts are opportunistically biased.

Research in finance and accounting documents in other settings rounding that does not necessarily result from heaping. In the finance literature, prior research documents clustering of share prices or returns on round values, which may represent either dealer collusion (Christie, Harris and Schultz 1994; Christie and Schultz 1994) or naturally occurring discontinuities in distributions (Osborne 1962; Grossman, Miller, Cone, Fischel, and Ross. 1997; Johnson, Johnson, and Shanthikumar 2011; Bhattacharya, Holden, and Jacobsen 2012). Amiram, Kalay, and Ozel (2013) show that bond coupon rates are set in increments of eighths. In the financial accounting literature, researchers find patterns consistent with rounding of unscaled reported

\footnotetext{
${ }^{6}$ For example, individuals tend to report round numbers for estimates of income (Turner 1958), age (e.g., Shryock, Siegel, and Larmon 1980; Roberts and Brewer 2001; A'Hearn, Baten, and Crayen 2009), weight and height (Rowland 1990), and blood pressure (Wen, Kramer, Hoey, Hanley, and Usher 1993).
} 
earnings and of reported earnings per share (EPS). ${ }^{7}$ These researchers ascribe the frequency of rounding to earnings management to meet or beat earnings benchmarks. Zhou (2010) and Cheong and Thomas (2011) document unusual patterns in forecasts of EPS. Amiram, Bozanic, and Rouen (2015) find that deviations of financial statement information from predicted distributions indicate financial reporting irregularities.

Prior research also explores discontinuities in the distribution of executive compensation that are not related to heaping: salaries of $\$ 0 / \$ 1$ and of $\$ 1$ million. Hamm et al. (2015) and Loureiro et al. (2015) investigate the prevalence of and reasons for salary grants of $\$ 0$ or $\$ 1$. More closely related to our research, Rose and Wolfram (2000, 2002) and Perry and Zenner (2001) identify increased clustering in executive salaries at $\$ 1$ million subsequent to introduction of Internal Revenue Code Section 162(m), which limits the tax deductibility of top executives' nonperformance-based compensation to $\$ 1$ million per year.

\section{HYPOTHESIS DEVELOPMENT}

\section{Is the Distribution of Executive Compensation Consistent with Heaping?}

Determining executive compensation schemes and values is a substantial task for boards of directors and the information acquisition and processing required for this task are costly activities for directors. However, pressure from other board members, shareholders, other stakeholders, or reputation concerns can provide directors incentives to engage in information acquisition and processing, i.e., to gather and understand more, or more precise, information (e.g., Bertrand and Mullanaithan 2001; Bebchuk and Fried 2003). Directors who undertake less information acquisition or spend less time processing information related to executive

\footnotetext{
${ }^{7}$ See, among others, Carslaw (1988), Thomas (1989), Hayn (1995), Burgstahler and Dichev (1997), Degeorge, Patel, and Zeckhauser (1999), Das and Zhang (2003), Bamber et al. (2010), Jorgensen, Lee, and Rock (2014), Malenko and Grundfest (2014), and Burgstahler and Chuk (2015, 2017).
} 
performance and compensation practices will be, on average, less informed than those who expend more effort, resulting in greater uncertainty about CEO performance and how to reward it. This leads to our first research question: Is the distribution of executive compensation consistent with heaping? We generate three hypotheses from this research question.

If heaping occurs when boards set executive compensation, we expect to observe a disproportionate number of round values of compensation grants. We also expect the frequency of round compensation to vary predictably, as we discuss in this section.

Numerous studies demonstrate that certain characteristics of boards of directors are consistent with weak oversight of managers and specifically, of executive compensation (e.g., Core et al. 1999; Coles et al. 2014). In such firms, we expect that directors will be less likely to have acquired and processed the information necessary to make precise, certain estimates about executive performance. This may arise because boards do not challenge powerful executives who take measures to obfuscate relevant information about performance, resulting in less precise information for decision-making. This may also arise if the directors of such boards are less responsive to pressure from outside parties or are not as motivated by reputation concerns. We thus expect boards with characteristics consistent with weak oversight of compensation to have less, or less precise, information about executive performance. In turn, if heaping is reflected in compensation, these less-informed boards will be more likely to provide round values of compensation. This leads to our first hypothesis.

H1: Rounding of compensation is negatively associated with board strength.

Pressure from shareholders and other outsiders may influence boards of directors to improve oversight of compensation. Bertrand and Mullanaithan (2001) and Bebchuk and Fried (2003) refer to pressure from stakeholders as "outrage." According to this point of view, when 
faced with pressure from stakeholders, boards are less likely to adopt forms of compensation that embarrass directors or executives or that might reduce shareholders' willingness to re-elect board members. Empirical evidence suggests that boards adjust compensation practices due to stakeholder pressure. Johnson et al. (1997) find that boards respond to negative publicity by granting smaller increases in compensation and by increasing the sensitivity of cash pay to performance. Core et al. (2008) obtain similar results but demonstrate that these effects may be short-lived. Thomas and Martin (1999) document that following shareholder compensation proposals, boards reduce CEO compensation. Consistent with these results, Ertimur et al. (2011) find that shareholder activism targeting executive compensation results in reduced excess CEO compensation. Ertimur et al. (2018) observe a \$1.2 million reduction in CEO compensation following proxy advisors' recommendations that shareholders withhold votes from directors due to concerns about pay-for-performance sensitivity. Abernethy et al. (2015) find that, while firms in the United Kingdom adopted performance-vested stock option plans to quell public outrage, powerful executives influence the choice of performance measures in those plans.

Evidence on the effect of stakeholder pressure suggests that boards will increase their oversight efforts and that this increase in effort extends to compensation. Thus, when stakeholders increase their focus on compensation, we expect boards to expend more effort gathering information about executive performance and in determining compensation design and payments. As a result, boards will have more precise information about executive performance, and less uncertainty, resulting in less round compensation. Thus, if round compensation results from heaping, we expect a negative association between the frequency of rounding and stakeholder pressure. This leads to our second hypothesis.

H2: Rounding of compensation is negatively associated with stakeholder pressure. 
We next investigate the association between the level of compensation and whether compensation is round. Bebchuk and Fried (2003) suggest that self-interested managers take advantage of opportunities to extract rents from firms in the form of excess compensation. Consistent with Bebchuk and Fried (2003), many studies find evidence of CEO opportunism when boards exhibit characteristics of weak oversight (e.g., Core et al. 1999; Coles et al. 2014; Abernethy et al. 2015). If round compensation is consistent with heaping, then round compensation values can be indicative of boards that face more uncertainty when setting compensation. In these cases, self-interested CEOs may take advantage of these boards' uncertainty to gain excess compensation. Thus, if round compensation results from heaping, then, for a given level of firm performance, compensation will be higher when it is round. This leads to our third hypothesis:

H3: Ceteris paribus, round compensation is higher than non-round compensation.

\section{Is Heaping Associated with Firm Performance?}

In our first three hypotheses we investigate whether round compensation arises from a heuristic response to uncertainty, heaping. We posit that uncertainty about optimal executive compensation arises because information acquisition and processing are costly, but that pressures from other board members and stakeholders will lead some boards to invest more in information acquisition and processing about compensation. In this section, we investigate whether heaping is associated with firm performance. On the one hand, if heaping results when boards do not provide strong oversight of compensation and allow self-interested managers to extract material rents via compensation, heaping may be associated with poorer firm performance. On the other, hand, heaping of compensation may result from an efficient allocation of board attention. That is, directors have numerous responsibilities, all of which require costly information acquisition and 
processing. As such, some boards may rationally choose to invest less in information acquisition and processing when setting compensation, as their limited attention has greater impact when focused on other decisions or activities. Because of the conflicting nature of these predictions, we state our fourth hypothesis in the null form.

H4: Rounding of compensation is not associated with future performance.

\section{SAMPLE AND PRELIMINARY EVIDENCE ON ROUND COMPENSATION \\ FREQUENCY}

\section{Sample Design}

Our initial sample includes CEOs from firms covered by ExecuComp for the period 2007 through 2014. We begin our sample in 2007 because the SEC increased compensation disclosure requirements for top executives' equity holdings and cash bonus payments beginning in December 2006. We focus our analyses on CEOs because their compensation is likely to be the most visible. Our sample is reduced due to use of data from RiskMetrics, Compustat, and CRSP for our analyses. The resulting sample includes 10,897 CEO-years. We further exclude 598 CEOs in their first year of employment to alleviate concerns that our results are driven by any tendency to round compensation in the first year of employment. Our main sample thus includes 10,299 CEO-years, although we place additional restrictions on our data for several of our tests. We discuss these exclusions in the research design for each test and include the sample size associated with each test in the tables. Table 1 presents distributions of regression variables. Variable definitions are presented in the table and are described in the text below.

\section{Preliminary Evidence on the Frequency of Round Compensation}

The first step in our analysis is to explore the prevalence of round values for all forms of compensation. We consider six types of compensation grants, salary (ExecuComp variable 
SALARY), discretionary bonus (ExecuComp variable BONUS), non-equity incentive cash compensation (ExecuComp variable NONEQ_INCENT) and grants of options (ExecuComp variable OPTION_AWARDS_NUM) and equity compensation (ExecuComp variables EQ_TARG and SHARES_GRT). ${ }^{8}$

Figure 1, Panel A, presents a histogram of salary compensation for our initial sample of 10,299 CEOs. We truncate this histogram at $\$ 2$ million for presentation purposes. Consistent with Rose and Wolfram $(2000,2002)$, Figure 1, Panel A, suggests that a disproportionately large number of CEOs earn exactly $\$ 1$ million. Of the observations in the bin containing $\$ 1,000,000$ through $\$ 1,020,000,495$ represent observations in which CEOs earned exactly $\$ 1$ million in salary. In addition to the high frequency of salaries equal to $\$ 1$ million, Figure 1, Panel A, shows unusually high frequencies of salary compensation at other values. One large irregularity in the distribution occurs in the first bin, where salary is $\$ 0-\$ 20,000$. The distribution of salaries within the bin is not uniform; the bin is dominated by a significant number of CEOs (81) whose cash compensation is no more than $\$ 1$. The frequency of these observations is consistent with Hamm et al. (2015) and Loureiro et al. (2015). However, we note unusually high frequencies of salary compensation throughout the distribution, primarily at values evenly divisible by $\$ 100,000$ and, in particular, around $\$ 500,000, \$ 1.5$ million, and $\$ 2$ million.

We note similar irregularities around values divisible by $\$ 500,000$ in the histograms of bonus compensation (Panel B) and non-equity incentive compensation (Panel C). The pattern is less obvious when we investigate the distributions of equity granted in Panels D through F, although we observe irregularities at values evenly divisible by 100,000 shares. Overall, the

\footnotetext{
${ }^{8}$ We assume that boards grant equity compensation in numbers of shares rather than in estimated dollar values. We thus study the number of options or stock shares granted. This assumption biases us against finding significant results if firms grant estimated dollar values of equity instead of numbers of options or shares.
} 
histograms of the distributions of cash and equity compensation provide preliminary evidence that compensation tends to be disproportionately divisible by 100,000 .

Since our histograms present compensation levels in $\$ 20,000$ bins, we cannot conclude that the spikes we observe are due to rounded compensation (i.e., compensation that is evenly divisibly by 100,000 or 10,000 units). In further examination of the spikes in the histograms, we investigate the prevalence of observations that end in zero. ${ }^{9}$ We restrict this analysis to non-zero values of each type of compensation grant. In Table 2, we present the frequency of the last digit being zero based on whether the amount is evenly divisible by $\$ 1,000,000$ (or $1,000,000$ shares), $\$ 100,000$ (or 100,000 shares), or $\$ 10,000$ (or 10,000 shares). While rounding to values evenly divisibly by $1,000,100$ or 10 is common in our sample, we treat these observations as non-round in subsequent analyses because they are unlikely to be economically significant to either firms or executives. ${ }^{10}$ For ease of exposition, we refer to values evenly divisible by 10,000 units as round.

Table 2 demonstrates that discretionary bonuses are the most likely form of compensation to be round ( 40.9 percent of nonzero observations are evenly divisible by $\$ 10,000$ ), followed by salary (36.1 percent of observations are evenly divisible by $\$ 10,000)$. We note that forms of compensation that are more likely to be qualitative assessments of CEO performance (i.e., salary and discretionary bonuses), are those forms of compensation that are most likely to be round. This is consistent with heaping, because these forms of compensation more naturally lend themselves to estimation, presenting opportunity for heuristic responses to come into play.

\footnotetext{
${ }^{9}$ Benford's Law shows that initial digits appear with differing frequencies in many datasets. As discussed in Beer (2009) and shown by Diaconis (1977), this effect dissipates in digits farther from the left-most digit, so that, in large data sets with large values, the expected frequency of most digits converges to $10 \%$ in places at least two digits from the left. Since we are interested in the right-most digit, we cannot draw inferences regarding the expected frequencies of values ending in zero from either Benford's Law or Diaconis (1977).

${ }^{10} \mathrm{We}$ confirm that our results are qualitatively similar when we define round as any value ending in zero, other than zero itself.
} 
Performance-based compensation is a quantitative assessment of CEO performance and will therefore reflect less uncertainty. If the frequency of round compensation does not result from heaping, we would not expect the frequency of round compensation to vary systematically with whether the compensation tends to be quantitative or is more likely to be based on qualitative considerations.

Table 2 also provides evidence that equity incentive shares and other equity are the least likely to be round (10.1 percent and 11.1 percent of observations are evenly divisible by 10,000 shares, respectively). Non-equity incentive and option grants are very likely to be round; 18.4 percent of non-equity incentive grants and 23.8 percent of option grants are evenly divisible by 10,000 units. In comparison, two commonly used performance measures, earnings per share and stock price, end in zero only 9.3 percent and 11.3 percent of the time, respectively (not tabled).

Overall, our descriptive analyses lead us to conclude that rounding is extremely common and that rounding occurs not just around the last digit, but also at much larger magnitudes. In subsequent analyses, we investigate the determinants of rounding and the associations of rounding with compensation levels and firm performance.

\section{TESTS OF HYPOTHESES}

\section{Discretionary and Performance-Based Compensation}

Our primary analyses focus on components of compensation that tend to be explicitly based on firm performance, rather than on components that are discretionary in nature. By definition, performance-based compensation is based on CEO (or firm) performance; therefore, these grants are the result of a quantitative assessment. If directors expend more effort to acquire or process information about a CEO's performance, they should be able to provide more precise values of compensation. Discretionary compensation, however, is based on a qualitative 
assessment. Thus, even if directors expend additional cognitive effort in setting discretionary compensation, substantial uncertainty in the estimate will remain, because the inputs are not quantitative. That is, additional cognitive effort may not be useful in resolving the uncertainty around discretionary compensation grants due to their qualitative nature. If round compensation results from heaping, we expect discretionary compensation to be round more frequently than performance-based compensation regardless of whether the board expends additional effort to acquire and process information. The descriptive results reported above are consistent with this conjecture. In addition, because we do not expect discretionary compensation components to vary with proxies for board effort, by including these analyses, we can provide additional evidence that our results are not spurious.

\section{Round Compensation, Board Oversight, and Stakeholder Pressure}

\section{Primary Analyses}

Our first two hypotheses relate to when firms are more likely to grant round compensation. Hypothesis 1 predicts that compensation is more likely to be round in firms with weaker boards of directors, and Hypothesis 2 predicts that round compensation is negatively associated with stakeholder pressure. To test these hypotheses, we estimate the following equation:

$$
\begin{aligned}
& \text { PercentRound }_{t}=\alpha+\beta_{1} \text { Dual }_{t}+\beta_{2} \text { Insiders }_{t}+\beta_{3} \text { AppointedByCEO }_{t}+ \\
& \beta_{4} \text { PostSOP }_{t}+\beta_{5} \text { SDROA }_{t}+\beta_{6} \text { SDReturns }_{t}+\beta_{7} \text { Digits }_{t}+ \\
& \beta_{8} \text { NumComponents }_{t}+\text { YearFE }+ \text { IndustryFE }+\varepsilon_{t}
\end{aligned}
$$

For total compensation, we create a composite measure that captures how much of the CEO's compensation is round, PercentRoundAll. PercentRoundAll is the number of round compensation components granted divided by the total number of compensation components 
granted. ${ }^{11}$ We next aggregate compensation components by whether the compensation granted is discretionary of performance-based because as discussed above our hypotheses should hold only for performance-based compensation grants. We label salary and discretionary bonus compensation as "discretionary", and all other components (i.e., non-equity incentive plan compensation, option grants, equity incentive shares, and other equity grants) as "performancebased". PercentRoundPerformance (PercentRoundDiscretionary) is the number of round, nonzero, performance-based (discretionary) compensation components divided by the total number of non-zero, performance-based (discretionary) compensation components granted. We present distributions of these variables in Table 1. Overall, approximately 25 percent of granted compensation components are round. Consistent with Table 2, discretionary compensation is more likely to be round than is performance-based compensation. On average, 18 percent of performance-based compensation is round, whereas 36 percent of discretionary compensation is round. Sample sizes are smaller when we split compensation into performance-based and discretionary components because some CEOs do not receive any performance-based compensation, and other CEOs do not receive any discretionary compensation.

To test the association between board oversight and the frequency of round compensation, we examine measures of board oversight used in prior research. If the CEO has greater power over the board of directors, the CEO will be more likely to be able to withhold or obfuscate information about performance without repercussions from board members. In turn, the board will have less precise information upon which to base estimates of CEO effort.

\footnotetext{
${ }^{11}$ For example, suppose a CEO were granted three compensation components: round salary, round non-equity incentive compensation, and a non-round number of options. PercentRoundAll would take a value of 0.667 (two round components divided by three components granted). Further, PercentRoundDiscretionary would take a value of 1, because the only discretionary component granted (salary) is round. Finally, PercentRoundPerformance would take a value of 0.5 , because one of the two performance-based components is round; non-equity incentive compensation is round while the option grant is not round.
} 
Additionally, board members of firms with powerful CEOs may be less responsive to outside pressure, or reputation concerns, than they are to pressure from CEOs. Our first measure of CEO power over the board is Dual, an indicator variable set to one if the CEO is also the chairman of the board and zero otherwise. Prior literature posits that these CEOs exert more control over the board of directors (e.g., Core et al. 1999). Core et al. (1999) also suggest that boards with more insiders (Insiders) are less independent of management, allowing CEOs more power over decision-making. Insiders is the percentage of board members who are current or former employees or family members of current employees. We also include a measure of co-opted boards, measured by the number of outside directors appointed by the CEO as a percentage of board size (AppointedByCEO). These directors may be more sympathetic to the $\mathrm{CEO}$, and more likely influenced by the CEO (Core et al. 1999; Coles et al. 2014). Data on director characteristics are from RiskMetrics, and data used to determine the CEO hire date are from ExecuComp.

To test the association between round compensation and stakeholder pressure, we include an indicator variable, PostSOP, which equals one if the observation is from 2011 or later, and zero otherwise. We use the passage of compensation-related regulation on executive pay to proxy for stakeholder pressure (Sheehan 2012). The Say on Pay provision of the Dodd-Frank Act was passed in response to increased public concern regarding the nature and reporting of executive compensation. While passage of compensation-related regulations is the result of public concern, passage is not the result of an individual firm's governance environment or pay practices. As a result, prior literature considers these regulation changes as primarily exogenous shocks to governance. These regulatory changes provide more robust evidence that any association between stakeholder pressure and changes in the frequency of rounding does not 
result from endogeneity than do other measures of stakeholder pressure, such as shareholder proposals or media attention.

The Say on Pay provision requires firms to allow shareholders to vote on executive compensation packages. Although results of the vote required by Say on Pay are only advisory, Ertimur, Ferri, and Oesch (2013) document that more than half of firms with adverse Say on Pay vote outcomes change their compensation plans. Lo, Yang, and Zhang (2014) find that boards respond to shareholder disapproval by amending compensation policies. Taken together, these studies suggest that Say on Pay increased boards' accountability to shareholders for executive compensation and therefore, likely increased their effort in determining executive compensation. In our main analyses we investigate changes in the frequency of round compensation around passage of the Say on Pay provision of the Dodd-Frank Act. ${ }^{12}$ Balsam Boone, Liu, and Yin (2016) find that in anticipation of Say on Pay, firms made CEO compensation more performance-based. Abernethy et al. (2015) also find evidence that outrage leads to a greater emphasis on performance-based pay. This is consistent with our focus on performance-based compensation components.

If round compensation results from heaping and is consistent with weak board oversight (Hypothesis 1), we expect positive coefficients of Dual $\left(\beta_{1}\right)$, Insiders $\left(\beta_{2}\right)$, and AppointedByCEO $\left(\beta_{3}\right)$ in Equation (1). If rounding is negatively associated with shareholder pressure (Hypothesis 2), we expect a negative coefficient of PostSOP $\left(\beta_{4}\right)$ in Equation (1).

In addition to our variables of interest, Equation (1) includes controls for the level of rounding in compensation that are unrelated to board effort. The standard deviation of return on assets $(S D R O A)$ controls for the noise in performance measures, because noisy performance

\footnotetext{
${ }^{12}$ In sensitivity tests, we investigate changes in the frequency of round option grants following implementation of SFAS 123R, which focused on accounting for option grants.
} 
measures provide less precise estimates of performance and may result in more heaping by the board of directors. SDROA is measured as the standard deviation of $R O A_{t}$ for the three years ending in year $\mathrm{t}$, where $\mathrm{ROA}_{t}$ is earnings before interest and taxes scaled by average total assets. We also control for volatility in the operating environment, which may impair the board's ability to precisely measure CEO performance. We include the standard deviation of returns (SDReturns), which is the standard deviation of monthly returns for the 36 months ending in year t. Two control variables capture potential mechanical reasons that round compensation might result. First, we control for the number of digits in compensation granted (Digits), because larger values are more likely to be round. Second, we control for the number of components granted (NumComponents), though we do not have a prediction for the direction of the expected association. We include industry and year fixed effects in all specifications.

Because our dependent variables are bounded between zero and one, we follow Papke and Wooldridge (1996) and estimate Equation (1) using a probit fractional response model. ${ }^{13} \mathrm{We}$ include year and industry fixed effects to control for unobservable economic factors that are correlated with both the frequency of rounding and the determinants of interest.

Table 3, Panel A presents the main results of estimating Equation (1). ${ }^{14}$ We present the results of testing $\mathrm{H} 1$ in Columns 1 through 3. In this specification we do not include the variable PostSOP. Focusing on the first column, in which the dependent variable reflects the level of rounding across performance-based compensation components (PercentRoundPerformance), we find evidence consistent with our predictions. We find a positive and significant association $(\mathrm{p}<0.10$, one-tailed) between two of our proxies for CEO control over the board of directors,

\footnotetext{
${ }^{13}$ Our inferences are unchanged if we use an ordered logit or ordered logit model instead of a fractional response model.

${ }^{14}$ Our results are consistent when we include each variable of interest separately, then stack all variables together. For parsimony, we only report results when we include all variables in the same regression.
} 
Insiders and Dual, which is consistent with our first hypothesis that boards round compensation more when CEOs have more control over boards. However, we find no evidence that appointment by the CEO is associated with rounding of performance-based compensation; $\beta_{3}$ is not significantly different from 0 . In Columns 4 through 6 we add the indicator variable for the passage of Say on Pay. Consistent with Hypothesis 2, we find that the percentage of round compensation components is negatively associated with the passage of Say on Pay ( $p<0.01$, onetailed), suggesting that boards round compensation less when stakeholders pay more attention. These results are consistent with the explanation that round compensation results from heaping: the frequency of round compensation in performance-based compensation is positively associated with characteristics of boards that provide weak oversight of compensation, and negatively associated with shareholder pressure.

The evidence in Columns 2 and 3, and 5 and 6 is also consistent with our expectations. For example, in Column 6, where the outcome variable is PercentRoundAll, we detect positive associations between both the fraction of the board appointed by the CEO, and the fraction of the board who are insiders. We also find that the associations between round compensation and proxies for weak board oversight and stakeholder pressure tend to be driven by performancebased, rather than discretionary, compensation. That is, with one exception, the associations between our variables of interest and the outcome variable are significant in Columns 3 and 6 , where the outcome variable is PercentRoundAll, but are not significant in Columns 2 and 5, where the outcome variable is PercentRoundDiscretionary. The exception is that round discretionary compensation is more common when the board has a higher proportion of insiders.

We also find that the association between the noise in performance measures (SDROA) and the percentage of round compensation components is positive and significant $\left(\beta_{5}>0\right)$ in all 
specifications, again driven by performance-based compensation, which is consistent with boards of directors heaping when performance measures are noisier, resulting in more uncertainty about CEO performance. We detect no association between the standard deviation of returns (SDReturns) and the frequency of rounding. ${ }^{15}$

In additional analyses, presented in Table 3, Panel B, we consider whether the change in the level of rounding following passage of Say on Pay was the result of changes in associations between board characteristics and rounding frequency. To do so, we estimate a version of Equation (1) in which we interact all variables with the post-Say on Pay indicator, PostSOP. Specifically, the increase in stakeholder pressure may have affected firms with weaker oversight more strongly than firms with stronger oversight. If this is the case, the interaction terms of PostSOP and our measures of oversight (Dual, Insiders and AppointedbyCEO) will be negative, and the main effect of the PostSOP indicator will be zero. We find some evidence that the positive association between Insiders and the level of round performance-based compensation is driven by observations from the post-Say on Pay period, and some evidence that board members appointed during the CEO's tenure were more likely to grant round performance-based compensation prior to Say on Pay. However, no interaction term between PostSOP and any of our measures of oversight is negative. We continue to detect a significantly negative association between PostSOP and the frequency of round compensation. These results suggest that, on average, boards were affected by the increased pressure from stakeholders associated with Say on Pay regardless of the strength of their compensation oversight.

\footnotetext{
15 In unreported analyses, we estimate Equation (1), excluding Digits, by compensation decile. Results fail to provide evidence that our results are driven by the size of compensation granted. We estimate Equation (1) by compensation decile rather than number of digits, because we find evidence that some firms manage compensation up or down around round values. When we estimate Equation (1) by compensation decile, our results are consistent with the analyses we present in Table 3 . We note that the associations between our variables of interest and rounding of discretionary compensation components are stronger, however.
} 


\section{Additional Tests of Hypothesis 2}

We perform two additional tests of the effect of changes in the frequency of rounding following the passage of compensation-related regulation. In these additional tests, we perform tests of changes in the frequency of rounding around Say on Pay and around SFAS 123R, an earlier regulatory change that took effect in December 2005, affecting the treatment of option compensation expense.

As identification strategy, we use within-firm analysis to isolate the effect of shareholder pressure on rounding. In this changes analysis, we hold the firm constant, which controls for firm-level effects and facilitates identification of the impact of compensation-related regulations on boards' effort in setting compensation. Following Jagolinzer (2009), our comparisons within firms do not require assumptions about the functional form of how firm, board, corporate governance, and executive characteristics map into outcomes. Holding the firm constant between the pre- and post-periods also controls for the compensation size. Compensation size may impact the likelihood of rounding, since higher magnitudes of compensation are more likely to be round.

Our first test of the effect of compensation-related regulation on rounding focuses on whether, on average, boards reduced heaping following passage of Say on Pay. Our sample for this test includes two years before and two years after the adoption of Say on Pay, resulting in an initial sample size of 6,986 CEO-years; we again exclude first-year CEOs. We next partition this sample into pre-Say on Pay (2009-2010) and post-Say on Pay (2011-2012). For tests of the change in the frequency of round compensation for each type of compensation, we exclude grants of $\$ 0, \$ 1$, or zero shares from our analyses. We further restrict the sample to include only firms that granted each component of compensation in every_year from 2009 through 2012. 
Table 4, Panel A, reports the results of tests of the association between passage of Say on Pay and round compensation frequency. For each type of compensation (i.e., performance-based, discretionary, and total), we compare the mean of the frequency of round compensation values in the pre- and post-Say on Pay periods. Consistent with our expectations, we find that boards were less likely to grant round compensation amounts after Say on Pay. Our measure of rounding for performance-based compensation components is significantly lower following passage of Say on Pay; it decreased from 21.3 percent in the pre-Say on Pay period to 16.6 percent in the post-Say on Pay period $(\mathrm{p}<0.01)$. While we find no statistically significant effect for discretionary compensation components, our composite measure of rounding is significantly lower following passage of Say on Pay; it decreased from 26.9 percent in the pre-Say on Pay period to 24.2 percent in the post-Say on Pay period $(\mathrm{p}<0.01)$.

In Table 4, Panel B, we investigate the change in the frequency of round option grants (a performance-based compensation component) from before and after SFAS 123R. We limit this test to option grants because SFAS 123R specifically addressed option compensation, unlike Say on Pay, which had implications for all forms of compensation. For this test, we include the years 2004 through 2007 and partition the sample into pre-SFAS 123R (2004-2005) and post-SFAS 123R (2006-2007) periods. We exclude observations of zero options from our analysis, resulting in a sample size of 4,169 CEO-years with nonzero option grants. We again restrict our sample to include firms that granted options in each year of the sample period. ${ }^{16}$ We find that boards are less likely to grant round option compensation following passage of SFAS 123R; the frequency of rounding to amounts evenly divisible by 100,000 or 10,000 decreased from 43.3 percent to 37.6 percent. We find that this change is significantly different from zero $(p<.01$, one-tailed $)$.

\footnotetext{
${ }^{16}$ Our results are qualitatively similar if we do not restrict the sample such that each firm appears in both the preand post-SFAS $123 \mathrm{R}$ periods.
} 
Taken together, the evidence in Table 4 indicates that regulation that highlights the treatment of compensation is associated with lower frequencies of round compensation. This, in turn, is consistent with the round compensation we observe resulting from heaping: when boards increase the effort they expend in setting compensation, they are less likely to provide round compensation grants.

\section{Round Compensation and Compensation Levels}

To test Hypothesis 3, that compensation is higher when boards grant round compensation, we test whether, controlling for economic determinants of compensation and determinants of rounding, the level of compensation is higher when compensation is round. To do so, we estimate the following equation:

Compensation $_{t}=\alpha+\beta_{1}$ PercentRound $_{t}+\beta_{2}$ Dual $_{t}+\beta_{3}$ Insiders $_{t}+$ $\beta_{4}$ AppointedByCEO $_{t}+\beta_{5}$ SDROA $_{t}+\beta_{6}$ SDReturns $_{t}+\beta_{7}$ Digits $_{t}+$ $\beta_{8}$ NumComponents ${ }_{t}+\delta_{1-8}$ Compensation Controls + YearFE + IndustryFE $+\varepsilon_{t}$

In our primary analysis, we estimate Equation (2) with the dependent variable measured as performance-based compensation (PerformanceCompensation), which is the sum of nonequity incentive plan compensation, the value of option grants, and the value of stock grants. We also report results using the dependent variable DiscretionaryCompensation, defined as the sum of salary and discretionary bonus, and as TotalCompensation, defined as the sum of all compensation components. We again expect our results to be weaker for discretionary compensation than performance-based compensation. All compensation measures are in logs. PercentRound refers to PercentRoundPerformance, PercentRoundDiscretionary, and PercentRoundAll measured as discussed above. If round compensation is consistent with heaping, and the corresponding lack of board effort in setting compensation allows self- 
interested managers to gain excess compensation, then $\beta_{1}$ will be greater than zero for performance-based compensation.

We include controls for the probability of rounding, as in Equation (1), Dual, Insiders, AppointedByCEO, Digits, NumComponents, SDROA, and SDReturns, which are likely also correlated with the level of compensation. In addition, we include common economic predictors of compensation levels (Core et al. 2008). $R O A_{t}\left(R O A_{t-1}\right)$ is return on assets measured as earnings before interest and taxes scaled by average total assets measured in year $\mathrm{t}(\mathrm{t}-1) . R E T_{t}\left(R E T_{t-1}\right)$ is the 12-month buy-and-hold market return for fiscal year $\mathrm{t}(\mathrm{t}-1)$. LogSales $_{t-1}$ is the $\log$ of sales in year $\mathrm{t}-1 . B T M_{t-1}$ is the book value of assets divided by market value of assets in year $\mathrm{t}-1$. LogTenure is the log of CEO tenure. PercentOwned is the percent of total shares owned by the executive, as reported in ExecuComp. We again include year and industry fixed effects.

Table 5 presents the results of estimating Equation (2). We find that the coefficient of PercentRoundPerformance, reported in Column 1 , is positive and significant $(\mathrm{p}<0.01$, onetailed), which is consistent with our hypothesis that, controlling for firm performance and other economic determinants of compensation, round compensation is higher than non-round compensation. The coefficient of 0.084 implies that performance-based compensation is 8.8 percent higher when all its components are rounded compared to when no components are rounded. ${ }^{17}$ In Column 2 , the association between discretionary compensation rounding and the level of discretionary compensation is not statistically different from zero. However, reflecting the performance-based compensation results, the coefficient of PercentRoundAll is significantly positive in Column 3. These results are consistent with the explanation that round compensation

\footnotetext{
17 Since the independent variable in Equation (2) is natural logarithm of performance-based compensation, the economic magnitude of moving PercentRoundPerformance from zero to one is calculated as: $8.8 \%=\exp (0.084)-1$.
} 
results from heaping: boards that are less informed or expend less cognitive effort in setting compensation, both round compensation and excess compensation result.

\section{Round Compensation and Firm Performance}

The above analyses are consistent with heaping occurring when boards determine executive compensation. We observe abnormally high levels of round compensation values, and round compensation is consistent with a lack of information acquisition and processing regarding compensation. In our final analysis, we test whether round compensation is associated with future firm performance, controlling for common predictors of performance and determinants of rounding. We estimate the following equation using OLS regression:

$$
\begin{aligned}
& \text { ROA }_{t+1}=\alpha+\beta_{1} \text { PercentRound }_{t}+\beta_{2} \text { Dual }_{t}+\beta_{3} \text { Insiders }_{t}+ \\
& \beta_{4} \text { AppointedByCEO }_{t}+\beta_{5} \text { SDROA }_{t}+\beta_{6} \text { Compensation }_{t}+\beta_{7} \text { ROA }_{t}+ \\
& \beta_{8} \text { LogSales }_{t+1}+\text { YearFE }+ \text { IndustryFE }_{+}+\varepsilon_{t}
\end{aligned}
$$

We proxy for future firm performance using ROA from the period after which compensation is granted $\left(R O A_{t+1}\right)$, measured as earnings before interest and taxes scaled by average total assets measured in year $\mathrm{t}+1$. We measure firm performance using ROA following prior literature that demonstrates an association between current year compensation and future year ROA (e.g., Core, Holthausen and Larcker 1999; Hayes and Schaefer 2000). If round compensation reflects significant rent extraction by CEOs, then we should find a negative association between the frequency of rounding and future firm performance $\left(\beta_{1}<0\right)$. If, instead, heaping results from efficient allocation of board attention, we will not detect an association between round compensation and future firm performance ( $\beta_{1}$ not different from 0$)$.

We include several controls for determinants of future ROA. We measure $R O A_{t}$ and $S D R O A$ as previously discussed. We measure $\operatorname{LogSales}_{t+1}$ as the $\log$ of sales in year $\mathrm{t}+1$. We also 
include the level of compensation as a control to address concerns about mechanical associations about the frequency of rounding and levels of compensation. We include industry and year fixed effects in all specifications.

We present the results of estimating Equation (3) in Table 6. We find that round performance-based compensation is significantly positively associated with future firm performance. This result is consistent with efficient allocation of board attention. This positive association could result if current-period performance-based compensation reflects the board's private information about performance in period $t+1$, as proposed in Hayes and Schaefer (2000). Further, this positive association might arise if current period performance-based compensation is viewed as a "gift exchange" between the board and the executive proposed by Akerlof (1982).

We note the significantly negative association between round discretionary compensation and future firm performance. As we report in Column 2 of Table 5, we do not find that discretionary compensation is higher when CEOs receive round discretionary compensation components. Thus, we interpret this negative association between round discretionary compensation components and future firm performance as indicating the presence of agency conflicts, rather the direct cost of excess compensation when compensation is round. When we consider total compensation in the third column, we find no evidence that the percentage of round compensation components is associated with future performance. We therefore caution that this result does not resolve whether round compensation reflects efficient or inefficient allocation of effort in setting compensation.

\section{ADDITIONAL TESTS}

\section{Changes in Non-CEO Compensation}


One concern with our cross-sectional analysis of the change in round compensation frequency following passage of compensation-related regulations is that boards may respond to regulation by expending effort to change only the most visible compensation-that of the CEO. If so, we may observe different patterns in the response to compensation regulation for CEOs than for other executives. To address this concern, we perform our analyses of changes in rounding around Say on Pay again, but we construct the samples to include the CEO and the Chief Financial Officer (CFO). We test whether the effect of the regulation change was stronger for the most visible executive, the CEO, than for other executives. Again, Jagolinzer (2009) notes that such analyses control for firm-year characteristics by design because we match CEOs and CFOs within the same firm and for the same year.

We present the results of these analyses in Table 7. This analysis includes only firms where the CEO and CFO of a firm were granted each type of compensation in both 2009 and 2011, which allows us to make within firm-year comparisons. ${ }^{18}$ We exclude first-year CEOs and first-year CFOs from our sample. Table 7 provides evidence that CFOs are statistically significantly less likely to receive rounded compensation grants both before and after Say on Pay than are CEOs. Table 7 also reveals that rounding of CFO compensation generally decreased around Say on Pay for performance-based compensation.

Taken together, the results in Tables 3, 4, and 7 offer strong support for Hypothesis 2, that regulations governing compensation reduce the prevalence of round compensation.

\section{Sensitivity Analyses}

\footnotetext{
${ }^{18}$ We use only one year pre- and post-Say on Pay for this analysis because when we restrict our sample to include each type of compensation for each executive in all four years from 2009 through 2012 our sample is extremely limited.
} 
Our main results are robust to several sensitivity tests. In our analyses, we do not differentiate between exactly $\$ 1$ million salary observations and other round salary observations. Many of these salary observations are likely round not because of heaping but because the Internal Revenue Code limits the deductibility of non-incentive-based compensation to $\$ 1$ million (Rose and Wolfram 2000, 2002). We obtain qualitatively and quantitatively consistent results for all hypotheses when we treat these observations as non-round.

Finally, we assume that boards choose numbers of options or shares to grant for compensation, rather than choosing a value of grants and calculating the number of options or shares necessary to provide a desired level of compensation. When we assume that boards grant dollar values of option or equity compensation, we find that the dollar value of options is evenly divisible by $\$ 10,000$ in 3.5 percent of cases and that the dollar value of equity grants is evenly divisible by $\$ 10,000$ in 4.5 percent of cases. This is consistent with some boards rounding dollar values of option and equity grants, instead of numbers of option and equity grant shares. If some boards grant round dollar values of option or equity grants, the corresponding number of options or shares would also be round only if the fair value of the option or share is also round. This implies that results of our tests of the frequency of rounding option and equity grants (Figure 1, Panels D, E, and F and Table 2) are likely understated. We find that our results in Tables 3 through 7 are qualitatively similar when we use the dollar value of options or shares granted instead of the number of options or shares granted.

\section{CONCLUDING REMARKS}

We investigate whether round CEO compensation results from heaping, which is the tendency of imperfectly informed individuals to report round estimates of discrete, quantitative data (Turner 1958). We document that round compensation is quite common. Since boards may 
possess imperfect information due to a lack of investment in information acquisition and processing, we investigate whether round compensation is associated with various proxies for board inattention to compensation, including proxies for weak board monitoring, shareholder pressure, and excess compensation. Consistent with our expectations, we find evidence that rounding is positively associated with proxies for weak board monitoring. We also find that the incidence of round compensation decreases after passage of compensation-related regulation (i.e., Say on Pay and SFAS 123R), which is consistent with these regulations providing incentives for boards to exert greater effort to reduce uncertainty when determining compensation. Additional results provide evidence that round compensation tends to be higher than non-round compensation. This association suggests that round compensation could signal to shareholders that boards who grant round compensation are less attentive to compensation than other boards. As expected, our results are driven by performance-based compensation rather than discretionary compensation. We also investigate the association of heaping of compensation with future firm performance, but do not find consistent evidence. While we interpret our findings from the perspective of heaping as defined in the accounting literature, we acknowledge that other fields define heaping as a broader phenomenon that might also explain our results.

Our study is the first to investigate whether heaping explains the distribution of executive compensation, but several questions remain for future research. For example, we measure stakeholder pressure using changes in regulation. Other sources of stakeholder pressure may also affect how boards set compensation and the effects of behavior on compensation. Prior literature documents that publicity (e.g., Johnson et al. 1997; Core et al. 2008), shareholder proposals (e.g., Thomas and Martin 1999, Ertimur et al. 2011), and proxy advisor recommendations (e.g., Ertimur et al. 2018) affect how boards set compensation. Future research could further 
investigate whether these sources of pressure have similar effects on compensation. Finally, we measure single dimensions of firm performance and monitoring. Round compensation may affect board decision-making in other ways, such as the probability of CEO turnover.

Overall, our results suggest that corporate governance choices can have subtle effects on decision making by boards. It remains an open question whether round compensation results from a more general practice in firms to provide round numbers, including earnings and earnings per share. An investigation of whether round compensation is associated with rounding of other reported values might provide additional evidence of heaping.

\section{REFERENCES}

Abernethy, M., Y. Kuang, and B. Qin. 2015. The influence of CEO power on compensation contract design. The Accounting Review 90 (4): 1265-1306.

A'Hearn, B., J. Baten, and D. Crayen. 2009. Quantifying quantitative literacy: Age heaping and the history of human capital. The Journal of Economic History 69 (3): 783-808.

Akerlof, G. A. 1982. Labor contracts as partial gift exchange. The Quarterly Journal of Economics 97 (4): 543-569.

Amiram D, Z. Bozanic, and E. Rouen. 2015. Financial statement errors: Evidence from the distributional properties of financial statement numbers. Review of Accounting Studies 20 (4): $1540-1593$.

Amiram, D., A. Kalay, and N. B. Ozel. 2013. The bond discount puzzle. Working paper, Columbia University.

Athanasakou, V., and A. Simpson. 2016. Investor attention to rounding as a salient forecast feature. International Journal of Forecasting 32 (4): 1212-1233.

Balsam, S., J. Boone, H. Liu, and J. Yin. 2016. The impact of say-on-pay on executive compensation. Journal of Accounting and Public Policy 35 (2): 162-191.

Bamber, L. S., K. W. Hui, and P. E. Yeung. 2010. Managers' EPS forecasts: Nickeling and diming the market? The Accounting Review 85 (1): 63-95. 
Barecca, A.J., M. Guldi, J. M. Lindo, and G. R. Waddell. 2011. Saving babies? Revisiting the effect of very low birth weight classification. The Quarterly Journal of Economics 126 (4): 2117-2123.

Bebchuk, L. A., and J. M. Fried. 2003. Executive compensation as an agency problem. Journal of Economic Perspectives 17 (3): 71-92.

Beer, T. W. 2009. Terminal digit preference: Beware of Benford's law. Journal of Clinical Pathology 62 (2): 192.

Bertrand, M., and S. Mullainathan. 2001. Are CEOs rewarded for luck? The ones without principals are. The Quarterly Journal of Economics 116 (3): 901-932.

Bhattacharya, U., C. W. Holden, and S. Jacobsen. 2012. Penny wise, dollar foolish: Buy-sell imbalances on and around round numbers. Management Science 58 (2): 413-431.

Burgstahler, D., and E. Chuk. 2015. Do scaling and selection explain earnings discontinuities? Journal of Accounting and Economics 60 (1): 166-186.

Burgstahler, D., and E. Chuk. 2017. What have we learned about earnings management? Integrating discontinuity evidence. Contemporary Accounting Research 34 (2): 726-749.

Burgstahler, D., and I. Dichev. 1997. Earnings management to avoid earnings decreases and losses. Journal of Accounting and Economics 24 (1): 99-126.

Carslaw, C. A. P. N. 1988. Anomalies in income numbers: Evidence of goal oriented behavior. The Accounting Review 63 (2): 321-327.

Cheong, F. S., and J. Thomas. 2011. Why do EPS forecast error and dispersion not vary with scale? Implications for analyst and managerial behavior. Journal of Accounting Research 49 (2): 359-401.

Christie, W. G., J. H. Harris, and P. H. Schultz. 1994. Why did NASDAQ market makers stop avoiding odd-eighth quotes? The Journal of Finance 49 (5): 1841-1860.

Christie, W.G., and P. M. Schultz. 1994. Why do NASDAQ market makers avoid odd-eighth quotes? The Journal of Finance 49 (5): 1813-1840.

Coles, J. L., N. D. Daniel, and L. Naveen. 2014. Co-opted boards. Review of Financial Studies 27 (6): 1751-1796.

Core, J. E., W. Guay, and D. F. Larcker. 2008. The power of the pen and executive compensation. Journal of Financial Economics 88 (1): 1-25. 
Core, J. E., R. W. Holthausen, and D. F. Larcker. 1999. Corporate governance, chief executive officer compensation, and firm performance. Journal of Financial Economics 51 (3): 371-406.

Das, S., and H. Zhang. 2003. Rounding-up in reported EPS, behavioral thresholds, and earnings management. Journal of Accounting and Economics 35 (1): 31-50.

Dechow, P. M., and H. You. 2012. Analysts' motives for rounding EPS forecasts. The Accounting Review 87 (6): 1939-1966.

Degeorge, F., J. Patel, and R. J. Zeckhauser. 1999. Earnings management to exceed thresholds. Journal of Business 72 (1): 1-33.

Diaconis, P. 1977. The distribution of leading digits and uniform distribution mod 1. The Annals of Probability 5 (1): 72-81.

Dodd-Frank Wall Street Reform and Consumer Protection Act, Pub. L. No. 111-203, § 521, 124 Stat. 1376, 1899 (2010).

Ertimur, Y., F. Ferri, and V. Muslu. 2011. Shareholder activism and CEO pay. The Review of Financial Studies 24 (2): 535-592.

Ertimur, Y., F. Ferri, and D. Oesch. 2013. Shareholder votes and proxy advisors-Evidence from Say on Pay. Journal of Accounting Research 51 (5): 951-996.

Ertimur, Y., F. Ferri, and D. Oesch. 2018. Understanding uncontested director elections. Management Science 64 (7): 3400-3420.

Fedyk, T. 2007. Discontinuity in earnings reports and managerial incentives. Working paper, University of California, Berkeley.

Financial Accounting Standards Board. 1995. Statement of Financial Accounting Standards No. 123: Accounting for Stock-Based Compensation (Norwalk, CT: FASB).

Financial Accounting Standards Board. 2004. Statement of Financial Accounting Standards No. 123R: Share-Based Payment (Norwalk, CT: FASB).

Frydman, C., and D. Jenter. 2010. CEO compensation. Annual Review of Financial Economics 2 (1): 75-102.

Grossman, S. J., M. H. Miller, K. R. Cone, D. R. Fischel, and D. J. Ross. 1997. Clustering and competition in asset markets. Journal of Law and Economics 40 (1): 23-60. 
Hamm, S. J. W., M. J. Jung, and C. Wang. 2015. Making sense of one dollar CEO salaries. Contemporary Accounting Research 32 (3): 941-972.

Hayes, R. M., and S. Schaefer. 2000. Implicit contracts and the explanatory power of top executive compensation for future performance. The RAND Journal of Economics 31 (2): 273293.

Hayn, C. 1995. The information content of losses. Journal of Accounting and Economics 20 (2): $125-153$.

Healy, P. M. 1985. The effect of bonus schemes on accounting decisions. Journal of Accounting and Economics 7 (1-3): 85-107.

Herrmann, D., and W. B. Thomas. 2005. Rounding of analyst forecasts. The Accounting Review 80 (3): 805-823.

Huttenlocher, J., L. V. Hedges, and N. M. Bradburn. 1990. Reports of elapsed time: Bounding and rounding processes in estimation. Journal of Experimental Psychology. Learning, Memory, and Cognition 16 (2): 196-213.

Jagolinzer, A. D. 2009. SEC Rule 10b5-1 and insiders' strategic trade. Management Science 55 (2): 224-239.

Johnson, E., N. B. Johnson, and D. M. Shanthikumar. 2011. Round numbers and security returns. Working paper, University of California at Irvine.

Johnson, M. F., S. Porter, and M. B. Shackell. 1997. Stakeholder pressure and the structure of executive compensation. Working paper, University of Notre Dame.

Jorgensen, B. N., Y. G. Lee, and S. K. Rock. 2014. The shapes of scaled earnings histograms are not due to scaling and sample selection: Evidence from distributions of reported earnings per share. Contemporary Accounting Research 31 (2): 498-521.

Lo, K., S. Yang, and J. L. Zhang. 2014. Say on Pay votes and compensation practices. Working paper, The University of British Columbia.

Loureiro, G. R., A. K. Makhija, and D. Zhang. 2015. The ruse of a one-dollar CEO salary? Working paper, Ohio State University.

Malenko, N., and J. A. Grundfest. 2014. Quadrophobia: Strategic rounding of EPS data. Working paper, Stanford University. 
Melumad, N. D. 1989. Asymmetric information and the termination of contracts in agencies. Contemporary Accounting Research 5 (2): 733-753.

Osborne, M. F. M. 1962. Periodic structure in the Brownian motion of stock prices. Operations Research 10 (3): 345-379.

Papke, L. E., and J. M. Wooldridge. 1996. Econometric methods for fractional response variables with an application to $401(\mathrm{~K})$ plan participation rates. Journal of Applied Econometrics 11 (6): 619-632.

Perry, T., and M. Zenner. 2001. Pay for performance? Government regulation and the structure of compensation contracts. Journal of Financial Economics 62 (3): 453-488.

Roberts, J. M., and D. D. Brewer. 2001. Measures and tests of heaping in discrete quantitative distributions. Journal of Applied Statistics 28 (7): 887-896.

Rose, N. L., and C. D. Wolfram. 2000. Has the "million-dollar cap" affected CEO pay? The American Economic Review 90 (2): 197-202.

Rose, N. L., and C. D. Wolfram. 2002. Regulating executive pay: Using the tax code to influence chief executive officer compensation. Journal of Labor Economics 20 (S2): S138-S175.

Rowland. M. L. 1990. Self-reported weight and height. American Journal of Clinical Nutrition 52 (6): 1125-1133.

Sheehan, K. 2012. Say on Pay and the outrage constraint. In R. S. Thomas, J. G. Hill (Eds.) Research Handbook on Executive Pay. Research Handbooks in Corporate Law and Governance. Cheltenham, U.K., and Northampton, Mass.: Elgar, 255-283.

Shah, A. K., and D. M. Oppenheimer. 2008. Heuristics made easy: An effort-reduction framework. Psychological Bulletin 134 (2): 207-222.

Shryock, H. S., J. S. Siegel, and E. A. Larmon. 1980. The Methods and Materials of Demography. Washington, DC: U.S. Department of Commerce, Bureau of the Census.

Simon, H. A. 1990. Invariants of human behavior. Annual Review of Psychology 41 (1): 1-19.

Thomas, J. K. 1989. Unusual patterns in reported earnings. The Accounting Review 64 (4): 773 787.

Thomas, R. S., and K. J. Martin. 1999. The effect of shareholder proposals on executive compensation. University of Cincinnati Law Review 67 (4): 1021-1081. 
Turner, S. H. 1958. Patterns of heaping in the reporting of numerical data. Proceedings of the Social Statistics Section, American Statistical Association, Washington D.C.: 248-251.

Wen, S. W., M. S. Kramer, J. Hoey, J. A. Hanley, and R. H. Usher. 1993. Terminal digit preference, random error, and bias in routine clinical measurement of blood pressure. Journal of Clinical Epidemiology 46 (10): 1187-1193.

Zhou, L. 2010. Nickels not pennies: Granularity in analysts' EPS forecasts and forecast revisions. Journal of Accounting, Auditing and Finance 25 (2): 201-233. 
FIGURE 1

Distributions of Compensation

Panel A: CEO Salary Compensation

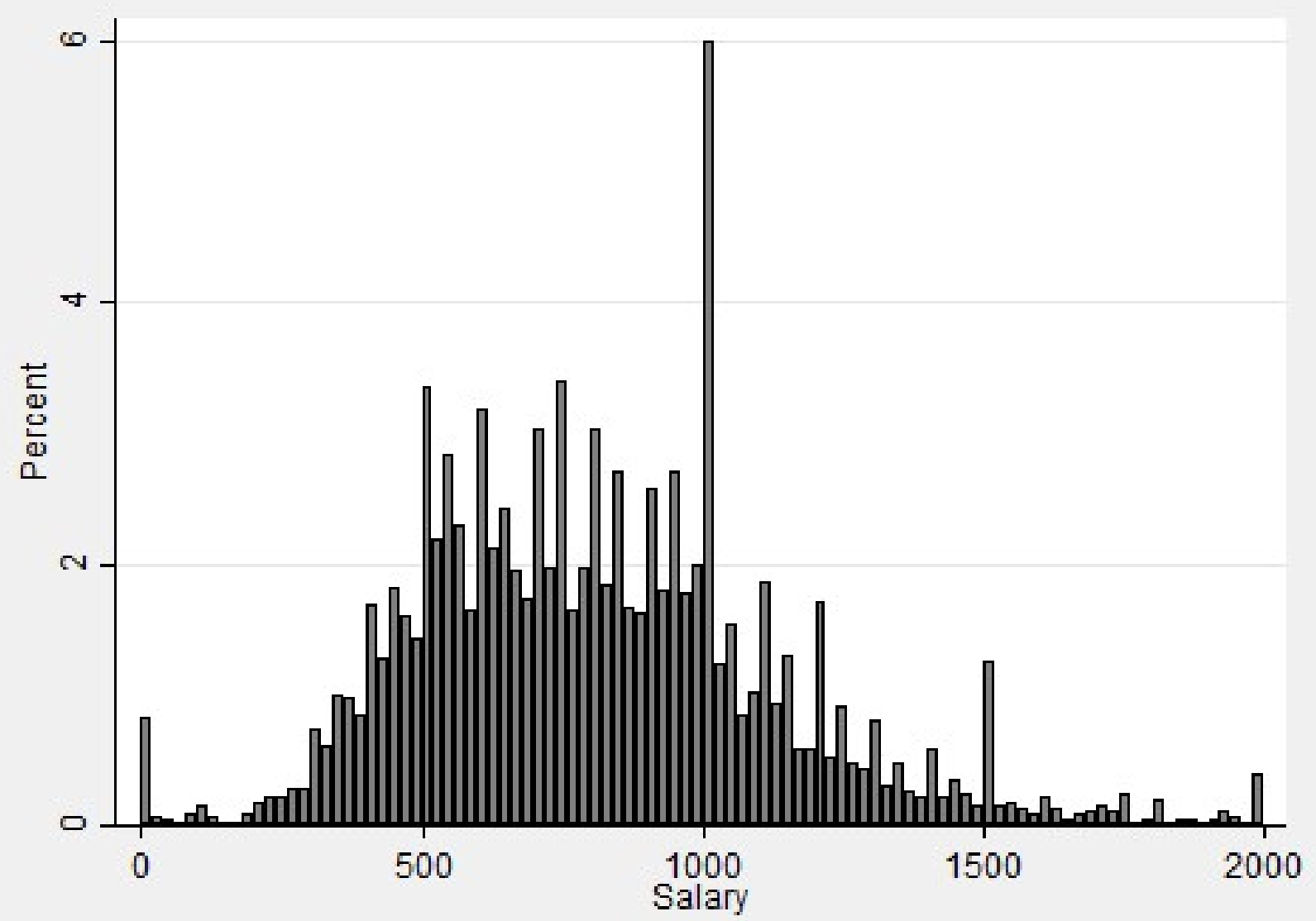

Salary is as reported by ExecuComp in $\$ 1,000$. The width of bins in the histogram is $\$ 20,000$. The sample size for this histogram is 10,299 CEO-years from 2007 to 2014. For legibility, we exclude 122 observations in which CEOs were granted more than $\$ 2,000,000$ in salary compensation, resulting in a sample size of 10,177 observations. 
Panel B: CEO Bonus Compensation

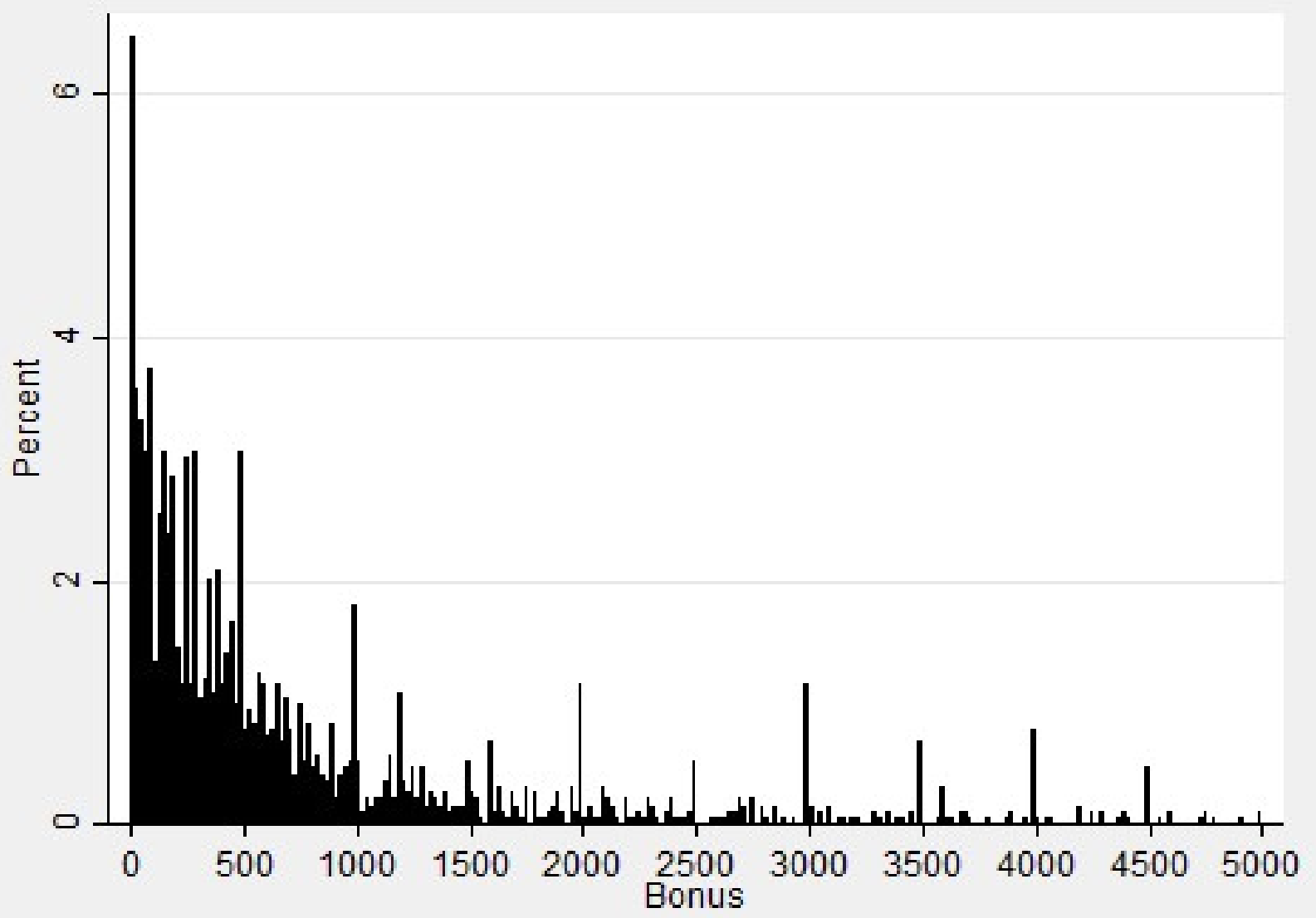

Bonus is as reported by ExecuComp in $\$ 1,000$. The width of bins in the histogram is $\$ 20,000$. The initial sample size for this analysis is 1,998 nonzero bonus grants. For legibility, we exclude 67 observations in which CEOs were granted more than $\$ 5,000,000$ in bonus compensation, resulting in a final sample size of 1,931 observations. 
Panel C: CEO Non-Equity Incentive Compensation

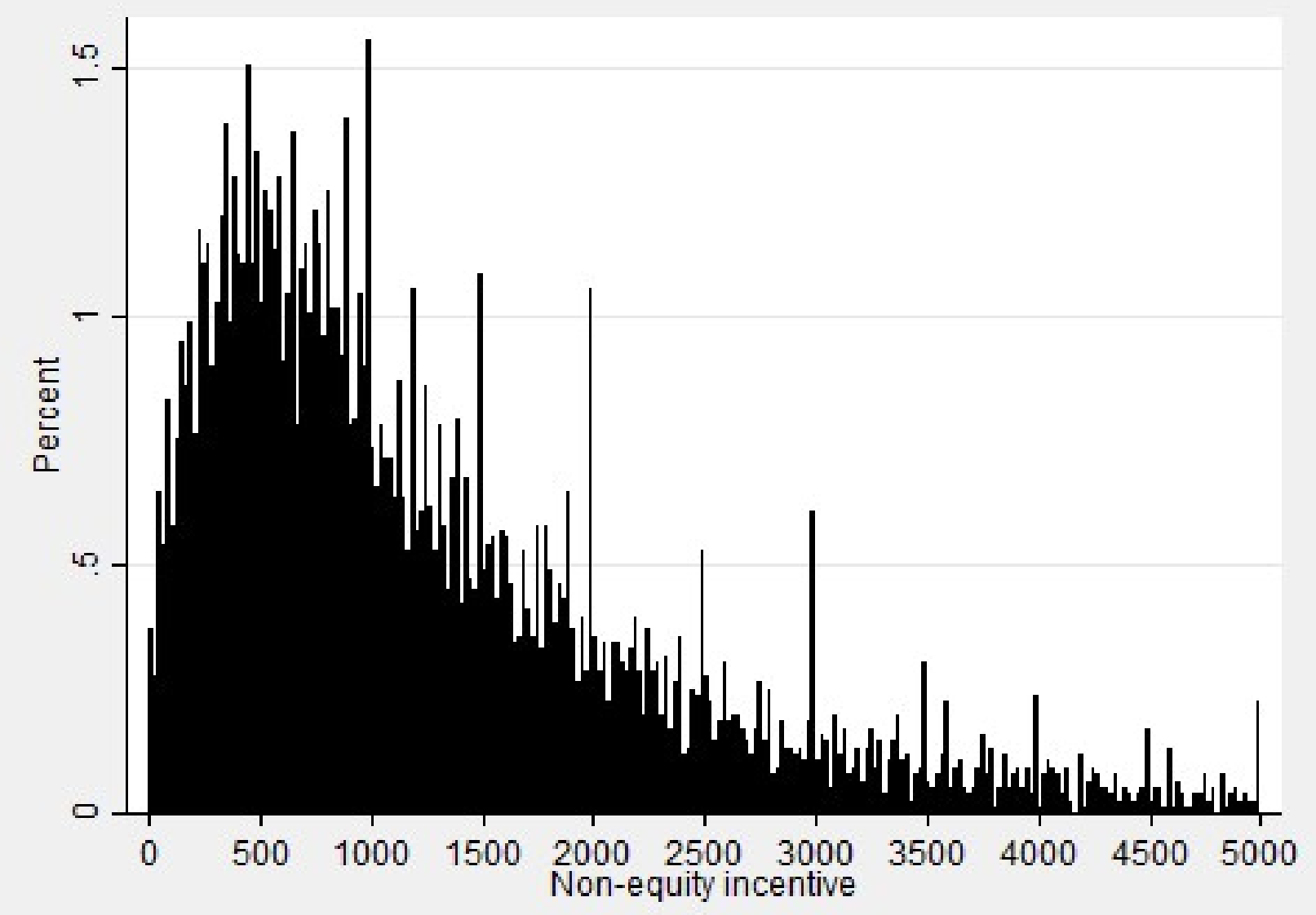

Non-equity incentive compensation is as reported by ExecuComp, in $\$ 1,000$. The width of bins in the histogram is $\$ 20,000$. The initial sample size for this analysis is 7,889 nonzero non-equity incentive grants. For legibility, we exclude 312 observations in which CEOs were granted more than $\$ 5,000,000$ in non-equity incentive compensation, resulting in a final sample size of 7,577 observations. 
Panel D: CEO Option Grants

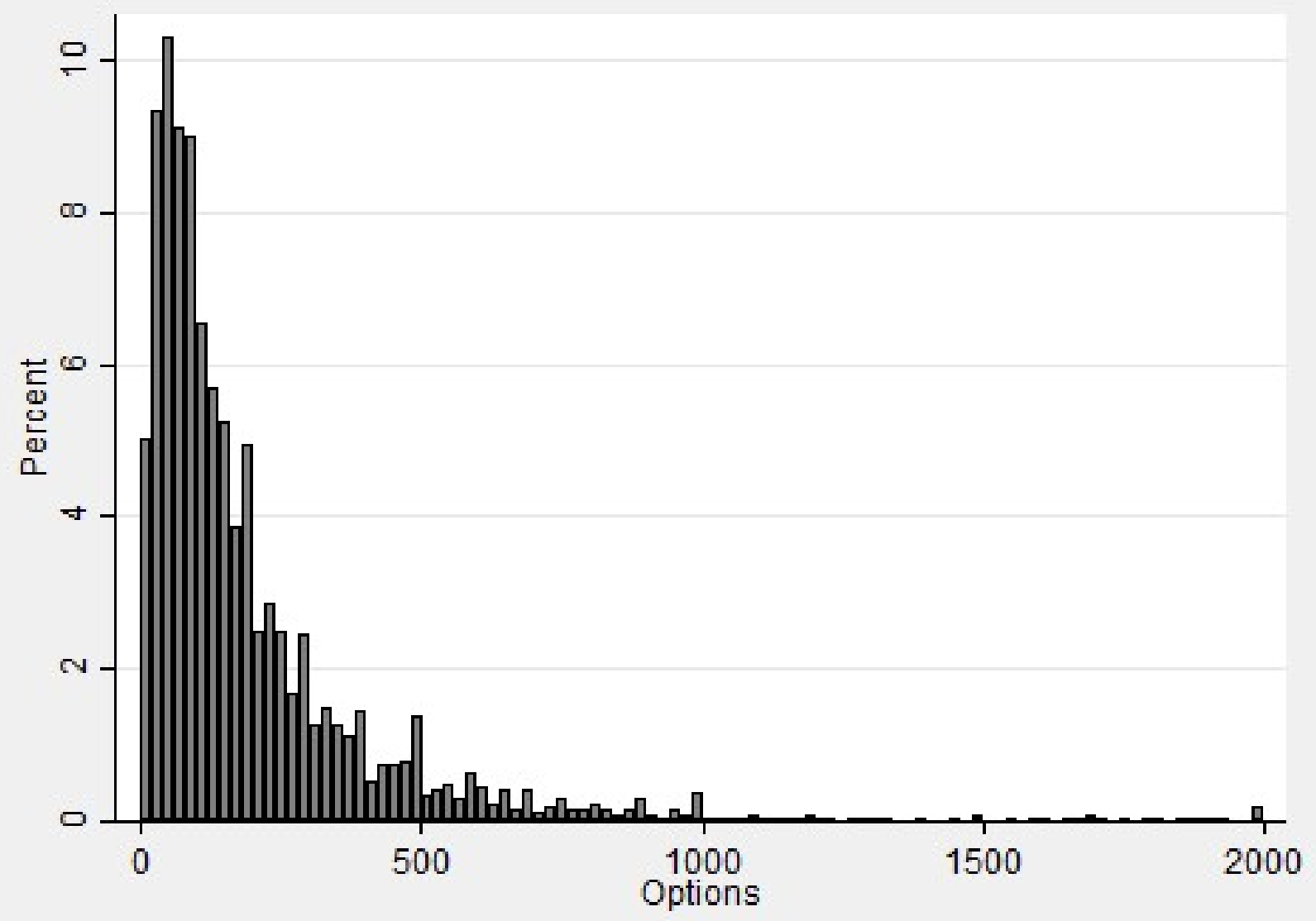

Options are the number of options granted as reported by ExecuComp, in 1,000 shares. The width of bins in the histogram is 20,000 . The initial sample size for this analysis is 5,540 non-zero option grants. For legibility, we exclude 36 observations in which CEOs were granted more than 2,000,000 options, resulting in a final sample size of 5,504 observations. 


\section{Panel E: CEO Equity Incentive Grants}

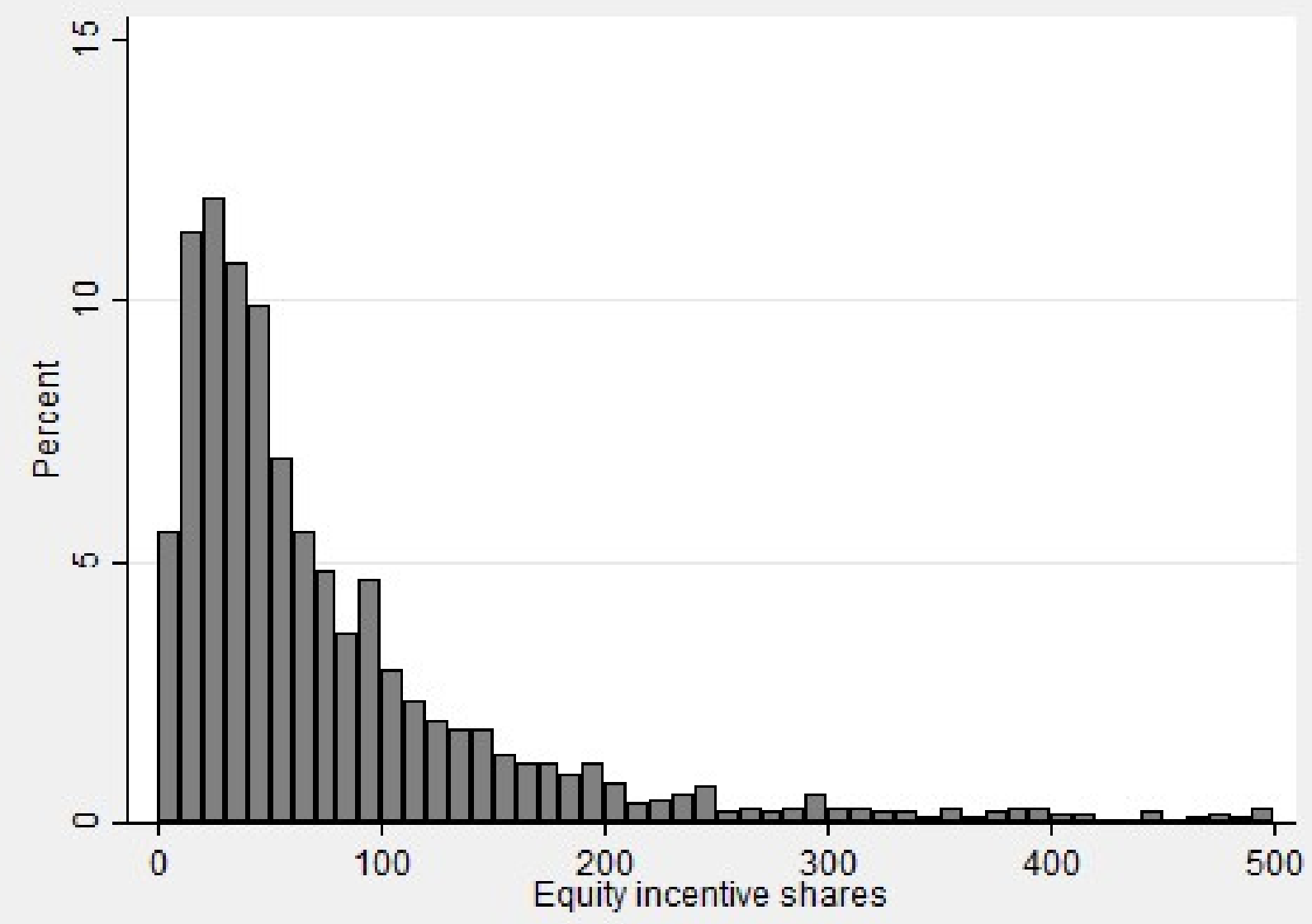

Equity incentive shares are the number of incentive shares granted as reported by ExecuComp in 1,000 shares. The width of bins in the histogram is 10,000 . The initial sample size for this analysis is 4,991 nonzero equity incentive grants. For legibility, we exclude 209 observations in which CEOs were granted more than 500,000 shares, resulting in a final sample size of 4,782 observations. 


\section{Panel F: CEO Other Equity Grants}

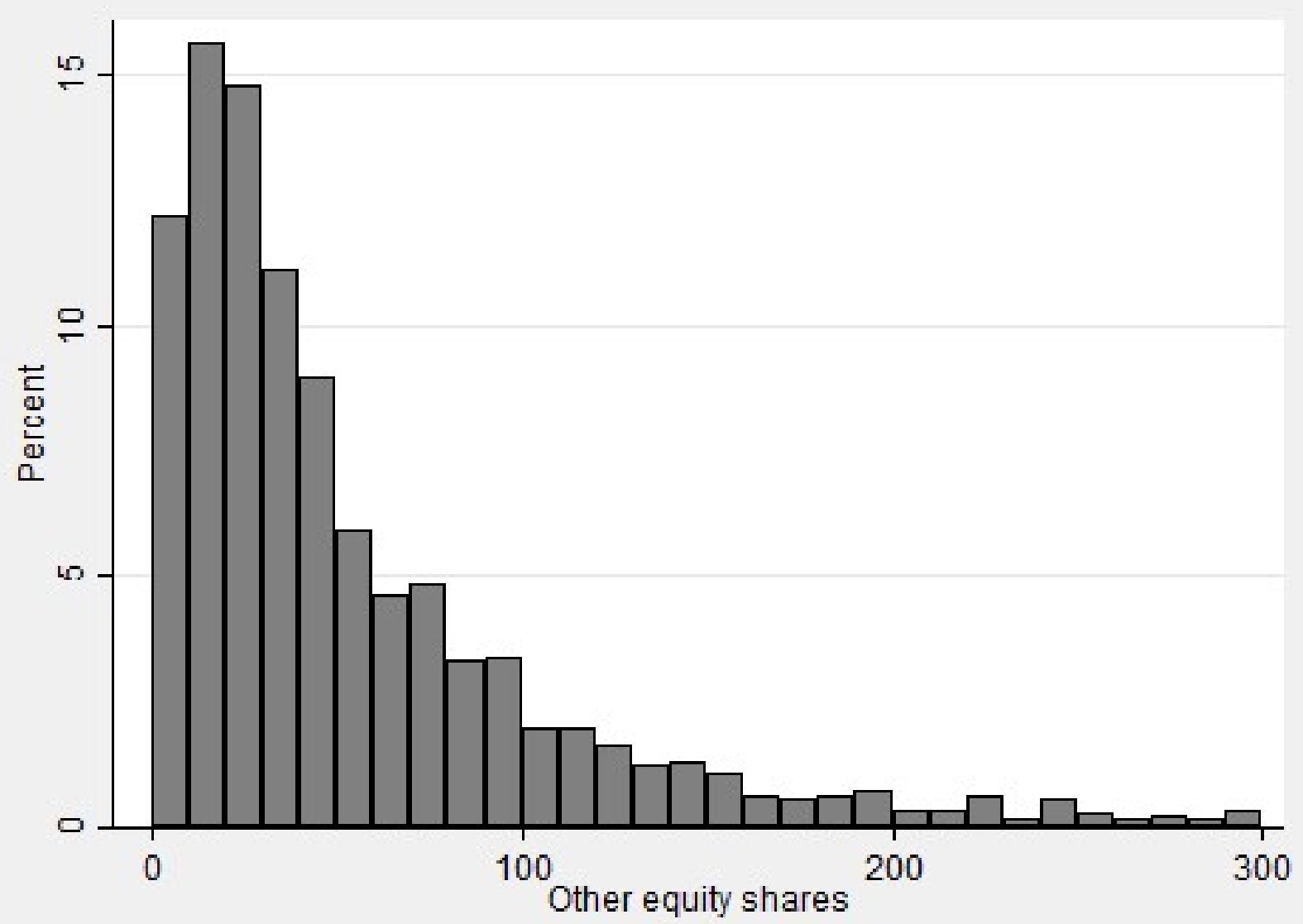

Other equity shares are the number of other equity shares granted as reported by ExecuComp in 1,000 shares. The width of bins in the histogram is 10,000 . The initial sample size for this analysis is 5,709 nonzero other equity grants. For legibility, we exclude 172 observations in which CEOs were granted more than 300,000 shares, resulting in a final sample size of 5,537 observations. 
TABLE 1

Distributions of Selected Regression Variables

\begin{tabular}{lrrrrr} 
Variable & Mean & Min. & Median & Max. & Observations \\
\hline PercentRoundAll & 0.247 & 0.000 & 0.250 & 1.000 & 10,299 \\
PercentRoundPerformance & 0.180 & 0.000 & 0.000 & 1.000 & 9,785 \\
PercentRoundDiscretionary & 0.361 & 0.000 & 0.000 & 1.000 & 10,279 \\
Dual & 0.540 & 0.000 & 1.000 & 1.000 & 10,299 \\
Insiders & 0.208 & 0.000 & 0.182 & 0.857 & 10,299 \\
AppointedbyCEO & 0.395 & 0.000 & 0.375 & 1.000 & 10,299 \\
PostSOP & 0.508 & 0.000 & 1.000 & 1.000 & 10,299 \\
TotalCompensation & $6,002.913$ & 0.001 & $4,147.181$ & $156,077.912$ & 10,299 \\
PerformanceCompensation & $4,664.123$ & 0.000 & $3,010.320$ & $151,141.922$ & 10,299 \\
DiscretionaryCompensation & $1,077.851$ & 0.000 & 855.000 & $77,926.000$ & 10,299 \\
ROA $A_{t+1}$ & 0.091 & -1.223 & 0.081 & 1.126 & 10,299
\end{tabular}

Compensation components, taken from ExecuComp, are round if they are evenly divisible by 100,000 or 10,000 dollars or shares. PercentRoundAll is the number of round components in a compensation package divided by the number of compensation components granted. PercentRoundPerformance is the number of round performancebased components in a compensation package divided by the number of performance-based components granted. Performance-based components include non-equity incentive compensation (the variable NONEQ_INCENT), the number of plan-based stock awards (EQ_TARG), the number of other shares granted (SHARES_GRT), and the number of options awarded (OPTION_AWARDS_NUM). PercentRoundDiscretionary is the number of round discretionary components in a compensation package divided by the number of discretionary components granted. Discretionary components include salary (SALARY) and bonuses awarded but not classified as part of a performance-based plan (BONUS). Dual is an indicator variable set to one if the CEO is also the chairman of the board and zero otherwise. Insiders is the percentage of board members who are insiders. AppointedByCEO is the percentage of outside board members appointed by the CEO. PostSOP is an indicator variable set to one if the observation is from 2011 or later. TotalCompensation is compensation as reported in ExecuComp, in thousands of dollars (TDC1). PerformanceCompensation is the sum of compensation from the four performance-based compensation components, as reported in ExecuComp (NONEQ_INCENT, OPTION_AWARDS_FV, and STOCK_AWARDS_FV), in thousands of dollars. Note that STOCK_AWARDS_FV summarizes the dollar value of EQ_TARG and SHARES_GRT, which are reported in shares. DiscretionaryCompensation is the sum of salary and discretionary bonus compensation from ExecuComp, in thousands of dollars. Following prior literature, we use the natural logs of compensation variables in our empirical analyses. $R O A_{t^{+1}}$ is return on assets measured as EBIT/average total assets measured in year $\mathrm{t}+1$. The sample size for this table is 10,299 . Not all CEOs were granted either performance-based compensation or discretionary compensation. 
TABLE 2

Frequency of Round Compensation Values for CEO-Year Observations with Compensation Greater Than or Equal to $\$ 100,000$

\begin{tabular}{|c|c|c|c|c|c|c|}
\hline & Salary & Bonus & $\begin{array}{l}\text { Non-equity } \\
\text { incentive }\end{array}$ & $\begin{array}{c}\text { Perforn } \\
\text { Options } \\
\end{array}$ & $\begin{array}{c}\text { nce-Based } \\
\text { Equity } \\
\text { incentive } \\
\text { shares }\end{array}$ & $\begin{array}{l}\text { Other } \\
\text { equity } \\
\text { shares }\end{array}$ \\
\hline $\begin{array}{l}\begin{array}{l}\text { Divisible by } 1,000,000 \quad(\$ \text { or } \\
\text { shares })\end{array}\end{array}$ & $5.3 \%$ & $4.9 \%$ & $2.4 \%$ & $0.8 \%$ & $0.2 \%$ & $0.1 \%$ \\
\hline Divisible by 100,000 (\$ or shares) & $14.4 \%$ & $17.6 \%$ & $7.4 \%$ & $7.8 \%$ & $2.6 \%$ & $1.8 \%$ \\
\hline Divisible by 10,000 ( $\$$ or shares) & $16.4 \%$ & $18.4 \%$ & $8.6 \%$ & $15.2 \%$ & $7.3 \%$ & $9.2 \%$ \\
\hline $\begin{array}{l}\text { Percent of observations evenly } \\
\text { divisible by } 10,000\end{array}$ & $36.1 \%$ & $40.9 \%$ & $18.4 \%$ & $23.8 \%$ & $10.1 \%$ & $11.1 \%$ \\
\hline Number of non-zero observations & 10,218 & 1,998 & 7,889 & 5,540 & 4,991 & 5,709 \\
\hline
\end{tabular}


TABLE 3

Predictions of Round Compensation Components

Panel A: Main Effects of Board Strength and Say on Pay

PercentRound $_{t}=\alpha+\beta_{1}$ Dual $_{t}+\beta_{2}$ Insiders $_{t}+\beta_{3}$ AppointedByCEO $_{t}+\beta_{4}$ PostSOP $_{t}+\beta_{5}$ SDROA $_{t}+$ $\beta_{6}$ SDReturns $_{t}+\beta_{7}$ Digits $_{t}+\beta_{8}$ NumComponents $_{t}+$ YearFE + IndustryFE $+\varepsilon_{t}$

\begin{tabular}{|c|c|c|c|c|c|c|c|}
\hline $\begin{array}{l}\text { PercentRound } \\
\text { refers to: }\end{array}$ & $\begin{array}{l}\text { Pred } \\
\text { Sign }\end{array}$ & (1) & (2) & (3) & (4) & (5) & (6) \\
\hline Dual & + & $\begin{array}{r}0.052^{*} \\
(1.43)\end{array}$ & $\begin{array}{l}-0.046 \\
(-1.15)\end{array}$ & $\begin{array}{l}0.009 \\
(0.33)\end{array}$ & $\begin{array}{l}0.021 \\
(0.58)\end{array}$ & $\begin{array}{l}-0.045 \\
(-1.10)\end{array}$ & $\begin{array}{l}-0.008 \\
(-0.28)\end{array}$ \\
\hline Insiders & + & $\begin{array}{r}0.336^{* *} \\
(1.94)\end{array}$ & $\begin{array}{r}0.263^{*} \\
(1.37)\end{array}$ & $\begin{array}{r}0.434 * * * \\
(3.28)\end{array}$ & $\begin{array}{r}0.284^{*} \\
(1.61)\end{array}$ & $\begin{array}{r}0.266^{*} \\
(1.38)\end{array}$ & $\begin{array}{r}0.401 * * * \\
(3.00)\end{array}$ \\
\hline AppointedByCEO & + & $\begin{array}{l}0.063 \\
(0.89)\end{array}$ & $\begin{array}{l}-0.011 \\
(-0.15)\end{array}$ & $\begin{array}{l}0.061 \\
(1.14)\end{array}$ & $\begin{array}{l}0.084 \\
(1.18)\end{array}$ & $\begin{array}{l}-0.012 \\
(-0.15)\end{array}$ & $\begin{array}{r}0.072^{*} \\
(1.34)\end{array}$ \\
\hline PostSOP & - & & & & $\begin{array}{r}-0.344 * * * \\
(-8.85)\end{array}$ & $\begin{array}{l}0.016 \\
(0.39)\end{array}$ & $\begin{array}{r}-0.193 * * * \\
(-6.86)\end{array}$ \\
\hline$S D R O A$ & + & $\begin{array}{r}1.351 * * * \\
(2.64)\end{array}$ & $\begin{array}{r}0.691^{*} \\
(1.34)\end{array}$ & $\begin{array}{r}0.944 * * \\
(2.30)\end{array}$ & $\begin{array}{r}1.350^{* * * *} \\
(2.61)\end{array}$ & $\begin{array}{r}0.691^{*} \\
(1.34)\end{array}$ & $\begin{array}{r}0.944^{* *} \\
(2.29)\end{array}$ \\
\hline SDReturns & + & $\begin{array}{l}0.048 \\
(0.92)\end{array}$ & $\begin{array}{l}-0.012 \\
(-0.17)\end{array}$ & $\begin{array}{l}0.035 \\
(0.84)\end{array}$ & $\begin{array}{l}0.050 \\
(0.96)\end{array}$ & $\begin{array}{l}-0.012 \\
(-0.17)\end{array}$ & $\begin{array}{l}0.034 \\
(0.82)\end{array}$ \\
\hline Digits & + & $\begin{array}{r}0.073 * * * \\
(2.60)\end{array}$ & $\begin{array}{r}0.451 * * * \\
(10.60)\end{array}$ & $\begin{array}{r}0.238 * * * \\
(8.96)\end{array}$ & $\begin{array}{r}0.081 * * * \\
(2.86)\end{array}$ & $\begin{array}{r}0.450^{* * * *} \\
(10.56)\end{array}$ & $\begin{array}{r}0.245^{* * *} \\
(9.19)\end{array}$ \\
\hline NumComponents & $?$ & $\begin{array}{r}-0.211 * * * \\
(-9.94)\end{array}$ & $\begin{array}{l}-0.050 \\
(-1.13)\end{array}$ & $\begin{array}{r}-0.192 * * * \\
(-13.33)\end{array}$ & $\begin{array}{r}-0.207 * * * \\
(-9.68)\end{array}$ & $\begin{array}{l}-0.049 \\
(-1.11)\end{array}$ & $\begin{array}{r}-0.190 * * * \\
(-13.15)\end{array}$ \\
\hline Constant & & $\begin{array}{r}-0.946 * * * \\
(-4.71)\end{array}$ & $\begin{array}{r}-3.277 * * * \\
(-12.43)\end{array}$ & $\begin{array}{r}-1.837 * * * \\
(-9.52)\end{array}$ & $\begin{array}{r}-0.791 * * * \\
(-3.87)\end{array}$ & $\begin{array}{r}-3.285^{* * *} \\
(-12.44)\end{array}$ & $\begin{array}{r}-1.762^{* * *} \\
(-9.10)\end{array}$ \\
\hline Observations & & 9,785 & 10,277 & 10,299 & 9,785 & 10,277 & 10,299 \\
\hline $\mathrm{R}^{2}$ & & 0.056 & 0.053 & 0.079 & 0.063 & 0.053 & 0.082 \\
\hline
\end{tabular}


TABLE 3

Predictions of Round Compensation Components

Panel B: Predictions of Round Compensation Components Including Interaction terms with PostSOP

\begin{tabular}{|c|c|c|c|c|}
\hline & $\begin{array}{c}\text { Pred. } \\
\text { Sign }\end{array}$ & (1) & (2) & (3) \\
\hline \multirow[t]{2}{*}{ Dual } & + & -0.005 & -0.034 & -0.004 \\
\hline & & $(-0.10)$ & $(-0.68)$ & $(-0.11)$ \\
\hline \multirow[t]{2}{*}{ Post*Dual } & $?$ & 0.052 & -0.019 & -0.009 \\
\hline & & $(0.93)$ & $(-0.32)$ & $(-0.23)$ \\
\hline \multirow[t]{2}{*}{ Insiders } & + & -0.037 & $0.408 * *$ & $0.282 * *$ \\
\hline & & $(-0.18)$ & $(1.85)$ & $(1.81)$ \\
\hline \multirow[t]{2}{*}{ Post ${ }^{*}$ Insiders } & $?$ & $0.732 * * *$ & -0.294 & $0.263 *$ \\
\hline & & $(2.92)$ & $(-1.14)$ & $(1.46)$ \\
\hline \multirow[t]{2}{*}{ AppointedbyCEO } & + & $0.127^{*}$ & -0.002 & $0.103 *$ \\
\hline & & $(1.43)$ & $(-0.02)$ & $(1.46)$ \\
\hline \multirow[t]{2}{*}{ Post ${ }^{*}$ AppointedbyCEO } & $?$ & -0.092 & -0.019 & -0.059 \\
\hline & & $(-0.85)$ & $(-0.16)$ & $(-0.73)$ \\
\hline \multirow[t]{2}{*}{ PostSOP } & - & $-0.490 * * *$ & 0.095 & $-0.220 * * *$ \\
\hline & & $(-5.76)$ & $(1.07)$ & $(-3.61)$ \\
\hline \multirow[t]{2}{*}{$S D R O A$} & + & $1.370 * * *$ & $0.689^{*}$ & $0.949 * *$ \\
\hline & & $(2.62)$ & $(1.34)$ & $(2.29)$ \\
\hline \multirow[t]{2}{*}{ SDReturns } & + & 0.048 & -0.011 & 0.033 \\
\hline & & $(0.91)$ & $(-0.16)$ & $(0.79)$ \\
\hline \multirow[t]{2}{*}{ Digits } & + & $0.082 * * *$ & $0.450 * * *$ & $0.245^{* * *}$ \\
\hline & & $(2.91)$ & $(10.56)$ & $(9.20)$ \\
\hline \multirow[t]{2}{*}{ NumComponents } & $?$ & $-0.206^{* * *}$ & -0.049 & $-0.190 * * *$ \\
\hline & & $(-9.64)$ & $(-1.10)$ & $(-13.15)$ \\
\hline \multirow[t]{2}{*}{ Constant } & & $-0.728 * * *$ & $-3.329 * * *$ & $-1.752 * * *$ \\
\hline & & $(-3.52)$ & $(-12.46)$ & $(-8.92)$ \\
\hline \multicolumn{2}{|l|}{ Observations } & 9,785 & 10,277 & 10,299 \\
\hline \multicolumn{2}{|l|}{$\mathrm{R}^{2}$} & 0.064 & 0.054 & 0.082 \\
\hline
\end{tabular}

In Panel A the dependent variable PercentRound refers to PercentRoundPerformance (Columns 1 and 4), or PercentRoundDiscretionary (Columns 2 and 5), or PercentRoundAll (Columns 3 and 6), as defined in the notes to Table 1. In Panel B the dependent variable PercentRound refers to PercentRoundPerformance (Column 1), or PercentRoundDiscretionary (Column 2), or PercentRoundAll (Column 3), as defined in the notes to Table 1. Dual is an indicator variable set to one if the CEO is also the chairman of the board and zero otherwise. Insiders is the percentage of board members who are insiders. AppointedByCEO is the percentage of outside board members appointed by the CEO. PostSOP is an indicator variable set to one if the observation is from 2011 or later. SDROA is the three-year standard deviation of $R O A_{t}$ measured as EBIT/average total assets measured in year t. SDReturns is the standard deviation of the prior 36 months of returns, ending in the year for which compensation is granted. Digits refers to the number of digits in values of PerformanceCompensation, DiscretionaryCompensation, or TotalCompensation, respectively. NumComponents is the number of performance-based compensation components (Column 1), the number of discretionary compensation components (Column 2), or number of compensation components in a compensation package (Column 3). The sample size for this table is 10,299 CEO-years from 20072014; we exclude observations in which the CEO was not granted discretionary (performance-based) compensation from Column 1 (Column 2). We estimate Equation (1) using a probit fractional response model. Standard errors are clustered by firm. This analysis includes industry and year fixed effects. ***, **, and * indicate statistical significance at $1 \%, 5 \%$, and $10 \%$ levels (one-tailed), respectively. 
TABLE 4

Changes in Frequency of Round Compensation Values around Passage of Compensation-Related Regulation Panel A: Change in the Frequency of Round Compensation Values Pre- and Post-Say on Pay

\begin{tabular}{|c|c|c|c|c|}
\hline & & $\begin{array}{c}\text { Percent of round } \\
\text { performance-based } \\
\text { components } \\
\text { PercentRoundPerformance } \\
\end{array}$ & $\begin{array}{c}\text { Percent of round } \\
\text { discretionary components } \\
\text { PercentRoundDiscretionary }\end{array}$ & $\begin{array}{c}\text { Percent of round } \\
\text { components } \\
\text { PercentRoundAll }\end{array}$ \\
\hline \multirow[t]{2}{*}{ Pre-Say on Pay } & $\%$ Rounded & $21.3 \%$ & $35.2 \%$ & $26.9 \%$ \\
\hline & Observations & 2,354 & 2,736 & 2,746 \\
\hline \multirow[t]{2}{*}{ Post-Say on Pay } & \% Rounded & $16.6 \%$ & $36.6 \%$ & $24.2 \%$ \\
\hline & Observations & 2,354 & 2,736 & 2,746 \\
\hline \multicolumn{2}{|c|}{ Pre- vs. Post- t-statistics } & $5.376 * * *$ & -1.131 & $3.518 * * *$ \\
\hline \multicolumn{5}{|c|}{ Panel B: Change in the frequency of round number of options granted pre- and post-SFAS 123R } \\
\hline \multicolumn{2}{|l|}{ Pre-SFAS 123R } & $\begin{array}{l}\% \text { Rounded } \\
\text { Observations }\end{array}$ & \multicolumn{2}{|l|}{$43.3 \%$} \\
\hline \multicolumn{2}{|l|}{ Post-SFAS 123R } & $\begin{array}{l}\% \text { Rounded } \\
\text { Observations }\end{array}$ & \multicolumn{2}{|l|}{$37.6 \%$} \\
\hline \multicolumn{3}{|c|}{ Pre- vs. Post- t-statistics } & \multicolumn{2}{|c|}{$2.401 * * *$} \\
\hline \multicolumn{5}{|c|}{$\begin{array}{l}\text { The frequencies reported in Panel A refer to PercentRoundPerformance (Column 1), PercentRoundDiscretionary } \\
\text { (Column 2), or PercentRoundAll (Column 1), as defined in the notes to Table } 1 \text {. The frequencies reported in Panel B } \\
\text { are the percentage of non-zero option grants that are evenly divisible by evenly divisible by } 100,000 \text { or } 10,000 \\
\text { shares. The pre-SOP period is 2009-2010, and the post-SOP period is } 2011-2012 \text {. The pre-SFAS } 123 \mathrm{R} \text { period is } \\
2004-2005 \text {, and the post-SFAS } 123 \mathrm{R} \text { period is } 2006-2007 \text {. The sample size for Panel A is } 6,986 \text { CEO-years; only } \\
\text { nonzero values of compensation are included in this analysis, and we exclude first-year CEOs. We further restrict } \\
\text { the sample for Panel A to include only firms that granted each component of compensation in } 2009,2010 \text {, } 2011 \text { and } \\
\text { 2012. The sample size for Panel B is } 6,676 \text { CEO-years from } 2004 \text { to } 2007 \text {, of which } 4,169 \text { are nonzero option grants. } \\
\text { We further restrict the sample for Panel B to include only firms that granted options in } 2004,2005,2006 \text { and } 2007 \text {. } \\
* * *, * * \text { and } * \text { indicate statistical significance at } 1 \%, 5 \% \text {, and } 10 \% \text { levels (one-tailed), respectively. }\end{array}$} \\
\hline
\end{tabular}




\section{TABLE 5}

\section{Associations of Round Compensation with Compensation Levels}

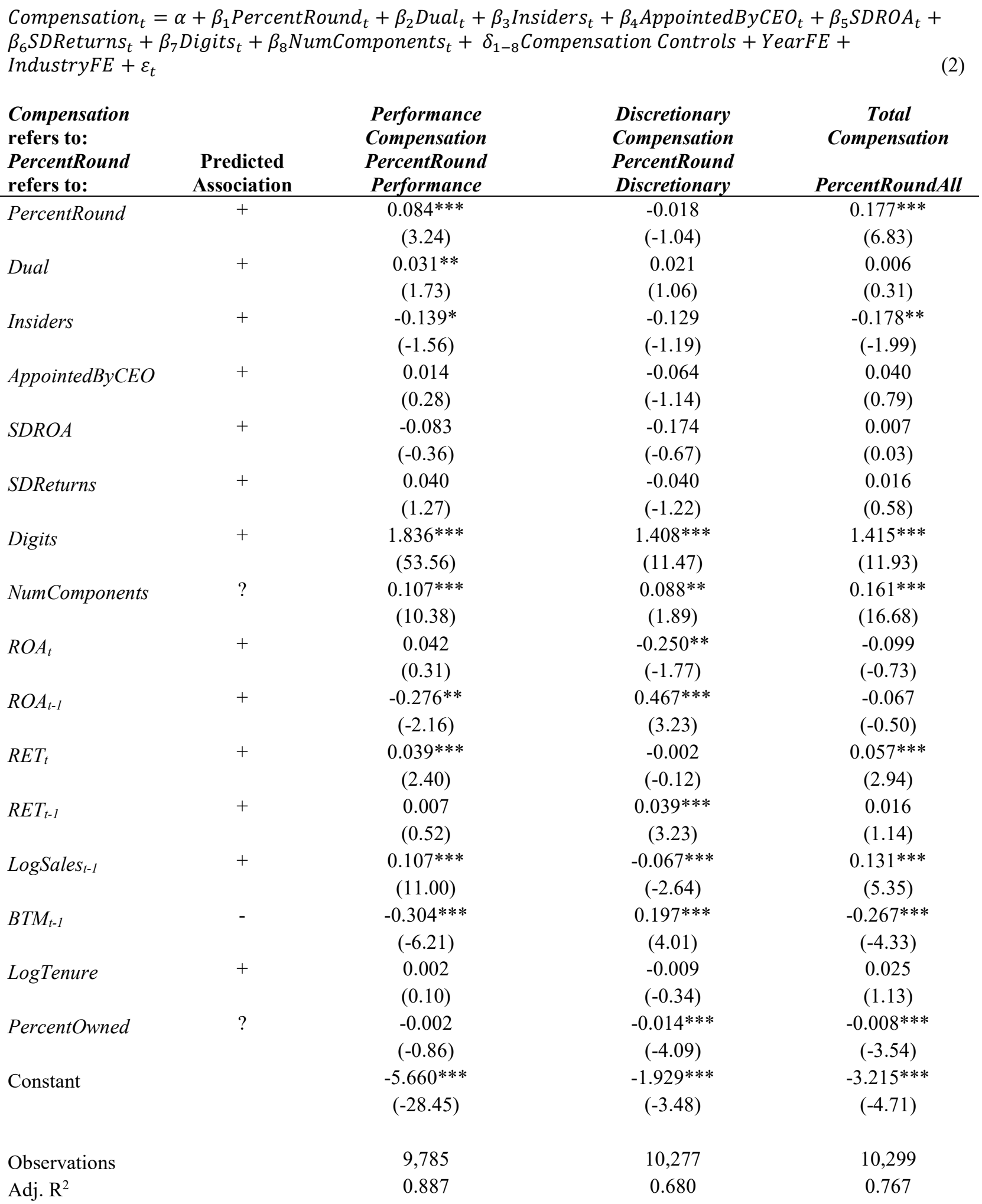


Compensation refers to PerformanceCompensation (Column 1), DiscretionaryCompensation (Column 2) or TotalCompensation (Column 3). PerformanceCompensation is the sum of compensation from the four performancebased compensation components, as reported in ExecuComp, in thousands of dollars. DiscretionaryCompensation is the sum of salary and discretionary bonus compensation from ExecuComp, in thousands of dollars. TotalCompensation is compensation as reported in ExecuComp, in thousands of dollars (TDC1). Following prior literature, we use the natural logs of compensation variables in our empirical analyses. PercentRound refers to PercentRoundPerformance (Column 1), PercentRoundDiscretionary (Column 2), or PercentRoundAll (Column 3), as defined in the notes to Table 1. Dual is an indicator variable set to one if the CEO is also the chairman of the board and zero otherwise. Insiders is the percentage of board members who are insiders. AppointedByCEO is the percentage of outside board members appointed by the CEO. $R O A_{t}\left(R O A_{t-1}\right)$ is return on assets measured as EBIT/average total assets measured in year $\mathrm{t}(\mathrm{t}-1)$. SDROA is the three-year standard deviation of ROAt. SDReturns is the standard deviation of the prior 36 months of returns, ending in the year for which compensation is granted. Digits refers to the number of digits in values of PerformanceCompensation, DiscretionaryCompensation, or TotalCompensation, respectively. NumComponents is the number of performance-based compensation components (Column 1), the number of discretionary compensation components (Column 2), or the number of compensation components in a compensation package (Column 3). Digits refers to the number of digits in values of PerformanceCompensation, DiscretionaryCompensation, or TotalCompensation, respectively. $R E T_{t}\left(R E T_{t-1}\right)$ is the 12-month buy-and-hold market return for fiscal year $\mathrm{t}(\mathrm{t}-1)$. LogSalest $t-1$ is the $\log$ of sales in year $\mathrm{t}-1$. BTM $\mathrm{t}_{t-1}$ is the book value of assets divided by market value of assets in year $\mathrm{t}-1$. LogTenure is the log of CEO tenure. PercentOwned is the percentage of total shares owned by the executive, as reported in ExecuComp. The sample size for this table is 10,299 CEO-years from 2007 to 2014. We estimate Equations (2) and (3) using OLS regression. Standard errors are clustered by firm. This analysis includes industry and year fixed effects. ***,**, and * indicate statistical significance at $1 \%, 5 \%$, and $10 \%$ levels (one-tailed), respectively. 


\section{TABLE 6}

\section{Associations of Round Compensation with Future Firm Performance}

\begin{tabular}{|c|c|c|c|c|}
\hline PercentRound refers to: & $\begin{array}{c}\text { Predicted } \\
\text { Association }\end{array}$ & $\begin{array}{c}\text { PercentRound } \\
\text { Performance }\end{array}$ & $\begin{array}{l}\text { PercentRound } \\
\text { Discretionary }\end{array}$ & PercentRoundAll \\
\hline PercentRound & $?$ & $\begin{array}{l}0.003^{* *} \\
(1.65)\end{array}$ & $\begin{array}{l}-0.002^{* *} \\
(-1.69)\end{array}$ & $\begin{array}{c}0.000 \\
(0.12)\end{array}$ \\
\hline Dual & - & $\begin{array}{r}0.001 \\
(1.00)\end{array}$ & $\begin{array}{r}0.001 \\
(0.64)\end{array}$ & $\begin{array}{r}0.001 \\
(0.68)\end{array}$ \\
\hline Insiders & - & $\begin{array}{l}0.014^{* * * *} \\
(2.52)\end{array}$ & $\begin{array}{l}0.013^{* * * *} \\
(2.42)\end{array}$ & $\begin{array}{l}0.012 * * \\
(2.20)\end{array}$ \\
\hline AppointedByCEO & - & $\begin{array}{l}-0.002 \\
(-1.01)\end{array}$ & $\begin{array}{l}-0.001 \\
(-0.62)\end{array}$ & $\begin{array}{l}-0.002 \\
(-0.66)\end{array}$ \\
\hline$S D R O A$ & $?$ & $\begin{array}{c}0.018 \\
(0.39)\end{array}$ & $\begin{array}{c}0.014 \\
(0.35)\end{array}$ & $\begin{array}{c}0.014 \\
(0.35)\end{array}$ \\
\hline Compensation & $?$ & $\begin{array}{r}0.000 \\
(0.19)\end{array}$ & $\begin{array}{l}-0.000 \\
(-0.55)\end{array}$ & $\begin{array}{l}-0.001^{*} \\
(-1.36)\end{array}$ \\
\hline$R O A_{t}$ & + & $\begin{array}{l}0.824^{* * *} \\
(38.68)\end{array}$ & $\begin{array}{l}0.822 * * * \\
(41.08)\end{array}$ & $\begin{array}{l}0.823^{* * *} \\
(41.06)\end{array}$ \\
\hline LogSales $_{t+1}$ & + & $\begin{array}{l}0.003^{* * *} \\
(5.06)\end{array}$ & $\begin{array}{l}0.003^{* * *} \\
(6.77)\end{array}$ & $\begin{array}{l}0.004 * * * \\
(6.51)\end{array}$ \\
\hline Constant & & $\begin{array}{l}-0.020^{* * *} \\
(-2.76)\end{array}$ & $\begin{array}{l}-0.016^{* * *} \\
(-2.47)\end{array}$ & $\begin{array}{l}-0.013^{* *} \\
(-1.98)\end{array}$ \\
\hline Observations & & 9,785 & 10,279 & 10,299 \\
\hline Adj. $R^{2}$ & & 0.634 & 0.638 & 0.638 \\
\hline
\end{tabular}

$R O A_{t+1}\left(R O A_{t}\right)$ is return on assets measured as EBIT/average total assets measured in year $\mathrm{t}+1$ ( $\left.\mathrm{t}\right)$. PercentRound refers to PercentRoundPerformance (Column 1), PercentRoundDiscretionary (Column 2), or PercentRoundAll (Column 1), as defined in the notes to Table 1. Dual is an indicator variable set to one if the CEO is also the chairman of the board and zero otherwise. Insiders is the percentage of board members who are insiders. AppointedByCEO is the percentage of outside board members appointed by the CEO. SDROA is the three-year standard deviation of ROA t. Compensation refers to PerformanceCompensation (Column 1), DiscretionaryCompensation (Column 2), or TotalCompensation (Column 3), as previously defined. Following prior literature, we use the natural logs of compensation variables in our empirical analyses. LogSales $t_{t+1}$ is the log of sales in year $\mathrm{t}+1$. The sample size for this table is 10,299 CEO-years from 2007 to 2014 . We estimate Equation (4) using OLS regression. Standard errors are clustered by firm. This analysis includes industry and year fixed effects. ***, $* *$, and $*$ indicate statistical significance at $1 \%, 5 \%$, and $10 \%$ levels (one-tailed), respectively. 
TABLE 7

Test of the Association between Round Compensation Grants and Passage of Say on Pay for CEOs and CFOs

\begin{tabular}{|c|c|c|c|c|}
\hline \multirow{3}{*}{\multicolumn{3}{|c|}{$\begin{array}{l}\text { CEO } \\
\text { Panel A: Percent of Round Performance-Based Components } \\
\text { Pre-Sav on nav }\end{array}$}} & CFO & \multirow[t]{2}{*}{$\begin{array}{c}\text { Compare CEO to CFO } \\
\text { t-statistics }\end{array}$} \\
\hline & & & & \\
\hline & & & $14.8 \%$ & $-6.606 * * *$ \\
\hline Pre-Say on pay & Observations & 1,309 & 1,309 & \\
\hline \multirow[t]{2}{*}{ Post-Say on pay } & $\%$ rounded & $17.2 \%$ & $9.6 \%$ & $-7.534 * * *$ \\
\hline & Observations & 1,309 & 1,309 & \\
\hline \multicolumn{2}{|c|}{ Pre- vs. Post- t-statistics } & $4.510 * * *$ & $5.230 * * *$ & \\
\hline \multicolumn{5}{|c|}{ Panel B: Percent of Round Discretionary Components } \\
\hline \multirow[t]{2}{*}{ Pre-Say on pay } & $\%$ rounded & $34.5 \%$ & $24.6 \%$ & $-6.353 * * *$ \\
\hline & Observations & 1,513 & 1,513 & \\
\hline \multirow[t]{2}{*}{ Post-Say on pay } & $\%$ rounded & $34.2 \%$ & $22.3 \%$ & $-7.731 * * *$ \\
\hline & Observations & 1,513 & 1,513 & \\
\hline \multirow{2}{*}{\multicolumn{2}{|c|}{$\begin{array}{l}\text { Pre- vs. Post- t-statistics } \\
\text { Panel C: Percent of Round Components }\end{array}$}} & 0.200 & $1.631 *$ & \\
\hline & & & & \\
\hline \multirow[t]{2}{*}{ Pre-Say on pay } & $\%$ rounded & $27.4 \%$ & $19.2 \%$ & $-8.120 * * *$ \\
\hline & Observations & 1,518 & 1,518 & \\
\hline \multirow[t]{2}{*}{ Post-Say on pay } & $\%$ rounded & $23.8 \%$ & $15.0 \%$ & $-9.590 * * *$ \\
\hline & Observations & 1,518 & 1,518 & \\
\hline \multicolumn{2}{|c|}{ Pre- vs. Post- t-statistics } & $3.400 * * *$ & $4.693 * * *$ & \\
\hline
\end{tabular}

The frequencies reported refer to PercentRoundPerformance (Panel A), PercentRoundDiscretionary (Panel B), or PercentRoundAll (Panel C), as defined in the notes to Table 1. The pre-SOP period is 2009, and the post-SOP period is 2011. The initial sample size for this table is 7,156 CEO- or CFO-years from 2009 and 2011; we exclude first year CEOs and first-year CFOs. We only include matched pairs of CEOs and CFOs, both of whom receive nonzero compensation in the pre- and post-periods. Finally, we require firms to be present in both 2009 and 2011. The resulting sample sizes for each analysis are included in panels above. $* * *, * *$, and $*$ indicate statistical significance at $1 \%, 5 \%$, and $10 \%$ levels (one-tailed), respectively. 


\section{University Library}

\section{- M M I N E R VA A gateway to Melbourne's research publications}

Minerva Access is the Institutional Repository of The University of Melbourne

\section{Author/s:}

Jorgensen, BN;Patrick, PH;Soderstrom, NS

Title:

Heaping of Executive Compensation

Date:

2020-04-21

Citation:

Jorgensen, B. N., Patrick, P. H. \& Soderstrom, N. S. (2020). Heaping of Executive

Compensation. Journal of Management Accounting Research, 32 (1), pp.177-201. https:// doi.org/10.2308/jmar-52477.

Persistent Link:

http://hdl.handle.net/11343/241655 